\title{
Political directors and corporate social responsibility: Are political ideology and regional identity relevant?
}

\author{
Pablo de Andres ${ }^{1}$ (D) . Inigo Garcia-Rodriguez ${ }^{2}$ (D) - M. Elena Romero-Merino ${ }^{2}$ (D) . \\ Marcos Santamaria-Mariscal $^{2} \mathbb{D}$
}

Received: 6 November 2020 / Accepted: 10 January 2022 / Published online: 9 February 2022

(c) The Author(s) 2022

\begin{abstract}
This study analyzes the influence of directors with political connections on corporate social responsibility (CSR). Using a sample of Spanish savings banks (cajas) during the period 2004-2013, we analyze the influence of political directors on the CSR of these entities, focusing on their ideology and regional identity. Our results indicate that the higher the proportion of directors with political ties on the board, the greater the allocation of resources to CSR activities. In addition to this positive effect of board politicization, we find that political directors' liberal ideology positively affects CSR, both directly and in moderating the relationship between political directors and CSR. Our results also validate that political directors' regional identity boosts the positive effect they have on CSR. Finally, we encounter various differences depending on the nature of the projects funded through CSR. Therefore, our study demonstrates the importance of delving into the characteristics of political directors to elucidate their effects on corporate policies.
\end{abstract}

Keywords Political directors · Ideology $\cdot$ Liberal $\cdot$ Regional identity $\cdot$ Board of directors $\cdot$ Corporate social responsibility $(\mathrm{CSR})$

JEL Classification G34 · G21 - G28 · M14

\section{Introduction}

In the current century, academic literature has emphasized the relevance of the presence of board members with political connections within companies (e.g., Guerra Pérez et al. 2015; Zhang et al. 2016; Xu and Liu 2020). Previous studies have noted

Inigo Garcia-Rodriguez

inigogr@ubu.es

1 Autonoma University of Madrid, Madrid, Spain

2 Department of Economy and Business Administration, Faculty of Economics and Business Administration, University of Burgos, C/ Parralillos s/n, 09001 Burgos, Spain 
both positive (e.g., more information, access to key resources) and negative (e.g., more social pressure, personal goals) aspects of such a political presence on the board of directors. However, the positive or negative effects of board politicization also depend on the specific area in which its impact is assessed. In this study, we focus on the impact of political directors on corporate social responsibility (hereinafter, CSR). CSR is configured as a corporate policy that enables firms to gain legitimacy from society. According to the literature, political directors find it especially convenient to increase CSR in order to improve both their own and company legitimacy (Lin et al. 2015; Wang et al. 2018; Yu and Chi 2021).

Typically, the literature has not delved into the different characteristics of political directors. Our research considers their heterogeneity as a group in order to explore their effect in greater depth, based on two characteristics that might define their behavior and corporate decision-making: their political ideology and regional identity. Regarding political ideology, the literature on corporate governance has recently emphasized its importance in corporate decision-making, and many studies have analyzed the impact of board and CEO ideologies on different corporate decisions in US firms. Political ideology is defined as an individual's set of moral and political attitudes that condition their beliefs about what society should be (Tedin 1987; Jost 2006). The traditional dimension of political ideology focuses on studying the difference between liberalism and conservatism. ${ }^{1}$ In this sense, from the point of view of individuals' behavior, people with a liberal ideology are distinguished by their concern about social and economic inequality (Jost 2006). From the point of view of corporate decision-making and as a natural consequence of these ideological values, previous literature has studied the influence of CEOs' liberal political ideology on the level of CSR (Chin et al. 2013; Di Giuli and Kostovetsky 2014). However, to the best of our knowledge, except for Di Giuli and Kostovetsky (2014), no existing studies address the influence of the liberal political ideology of board members on CSR.

In addition, political directors' regional identity can affect their decision-making. We approach the concept of regional identity based on social identity theory (Tajfel and Turner 1986; Abrams and Hogg 1990) and the literature on regional favoritism (Hodler and Raschky 2014; Fiva and Halse 2016; Chen et al. 2020). Social identity theory supports the notion that individuals exhibit biased behavior (favoritism and/or discrimination) in response to their self-identification of group membership. Social identity is the link that helps individuals to identify with the group (Crane and Ruebottom 2011). Specifically, group social identity is "a set of mutual understandings regarding the unique characteristics that distinguish (members) from nonmembers" (Rowley and Moldoveanu 2003, p. 208). One such type of social identity is nationality, and at the sub-national level, regional identity, ${ }^{2}$ which leads people

\footnotetext{
1 Although psychological and political sciences often refer to the left-right axis, prior literature on the corporate sphere has replaced this with the terms liberalism and conservatism, indifferently, since analysis has tended to focus on US firms (Carney et al. 2008; Tetlock et al. 2013). We follow this line of literature by using liberalism to identify left-wing ideology and conservatism to refer to right-wing ideology.

2 As Paasi (2003) notes, it is important to distinguish analytically between the identity of a region and the regional identity (or regional consciousness) of the people living therein. The former points to the characteristics of nature, culture, and people that are used in political, institutional, etc. discourse to dis-
} 
who identify with it to act in its favor (regional favoritism) by allocating greater public funding or greater investment in their regions. Although we have identified no studies that address the effect of this regional identity of political directors on CSR, we expect them to maintain a strong regional identity, an identity that will lead them to promote policies that favor spending in that region through greater CSR.

Therefore, the main objective of this study is to explore the effects of political directors on CSR, incorporating the influence of both their ideology and regional identity. Specifically, we consider the heterogeneity that may exist within this group of political directors, and include the impact that their personal characteristicspolitical ideology and regional identity — may have, both directly and indirectly, by moderating the effect of board politicization on CSR.

We test our hypotheses by analyzing the directors of a sample of Spanish savings banks (hereinafter, cajas) for the period 2004-2013. Cajas are a specific type of entity, with peculiarities that make these relationships especially interesting to study. These entities are private but have no owners, such that legislation distributes control rights among several stakeholders, with those of public administrations being dominant (Andres et al. 2021). In this study, therefore, we do not analyze independent directors with political ties, but rather directors who are representatives of public administrations. Thus, their objective was to defend the interests of society, with $\mathrm{CSR}^{3}$ emerging as an appropriate mechanism to achieve this. In fact, CSR was one of the hallmarks of Spanish cajas that enabled them to differentiate themselves from other financial entities, such as commercial banks, such that these directors had to meet society's expectations in terms of implementing social projects to achieve legitimacy for these entities. Moreover, one essential characteristic of cajas is that they maintain a strong link with the region in which they originated, not only in terms of their banking business, but also regarding their corporate governance. This leads to the presence of numerous political directors from different political ideologies and regional identities in these entities, which provides a unique opportunity to examine their influence on CSR policy.

Our results indicate that a greater presence of political directors on the board is related to higher CSR. We emphasize the importance of considering the heterogeneity of political directors since we also observe that this positive relationship is enhanced by both political directors' liberal ideology and regional identity. In the case of liberal political directors, we also find a direct effect, since the higher the percentage of political directors with this ideology, the greater the allocation of a caja's resources to its CSR. Further, we observe various differences depending on the nature of the projects funded through CSR. While liberal directors are especially

\footnotetext{
Footnote 2 (continued)

tinguish one region from another. Regional consciousness, on the other hand, points to people's identification with those institutional practices, discourses, and symbolisms.

3 In the case of Spanish cajas, CSR policy could be associated with the so-called "obra social" (social work). In this way, "Social work constitutes one of the fields for the application of Corporate Social Responsibility in the realm of savings banks" (Cabeza-García et al. 2010, p. 33). Here, although they are not completely synonymous, we use the term CSR.
} 
supportive of CSR in historical, artistic, and natural heritage projects, regionalist directors are more concerned with CSR related to education and research projects.

Our study contributes to the literature on corporate governance in several respects. First, we complement existing studies of directors' political conditions by exploring two unobservable characteristics, namely, their political ideology and regional identity. Specifically, we build upon the existing literature in determining how CEOs' liberal ideology influences the firm's CSR in the study of the board. In addition, we examine the effect of directors' regional identity on CSR policy, which is the first study to address this relationship. Second, the study is novel compared to most existing studies due to its focus on financial entities rather than non-financial companies. In this context, the consequences of directors' political conditions and values have greater repercussions because of the important externalities that financial entities have on society (e.g., promoting or restricting the financing of new investments). Third, our study adds another piece to the puzzle of the performance of political directors in the governance of Spanish cajas. Most previous studies have focused on the effect of board politicization on cajas' performance (Azofra and Santamaría 2004; García-Meca and Sánchez-Ballesta 2014; Andres et al. 2021), while few studies on CSR have been conducted. Finally, based on its results, our study provides guidelines for the configuration of the board of directors, emphasizing the importance of factors that extend beyond directors' independence or expertise.

The structure of this article is as follows: Sect. 2 addresses the theoretical framework that leads to our hypotheses. Section 3 explains the main features of the institutional context in which we test our hypotheses: Spanish cajas. In Sect. 4, we discuss the sample, model, and methodology used in this study. The results of the descriptive and explanatory analyses conducted to test the proposed hypotheses, including a robustness section, are presented in Sect. 5. Finally, Sect. 6 concludes the article with the discussion of the main results of the study, its theoretical contributions and practical implications, and its limitations and future research.

\section{Board politicization, political ideology, regional identity, and CSR}

According to legitimacy theory (Suchman 1995), organizations are part of a wider social system. As they coexist with multiple participants, they do not maintain an inherent right to obtain and use resources; such resources must be earned or deserved. To ensure access to the resources they need, and thus safeguard their survival and success, organizations must be accepted by the general public; that is, they are required to operate in accordance with the expectations of society if they are to achieve legitimacy (Li et al. 2015; Castelló et al. 2016; Deegan 2019). In this context, legitimacy is understood as "a generalized perception or assumption that the actions of an entity are desirable, proper, or appropriate within some socially constructed system of norms, values, beliefs, and definitions" (Suchman 1995, p. 574). Linked to social expectations, which may change depending on the period and place in which the organization operates, legitimacy is not static and, if the social system varies, organizations must again seek legitimization in accordance with the new circumstances (Deegan 2019). Those in charge of observing the different organizations 
and assessing their legitimacy need not necessarily belong to the organization or be specific stakeholders, but in many cases will be society at large (Castelló et al. 2016; Deegan 2019). For this reason, this theory is sometimes linked to the idea of a social contract, which comprises the set of expectations, both implicit and explicit, that society has about the organization and its operation. It is based on the expectation that the legitimacy of the organization has been assessed (Deegan 2019).

Organizations can influence the perceived legitimacy that society places on them (Dowling and Pfeffer 1975) by managing threats to legitimacy through various strategies, including CSR (Li et al. 2015; Garanina and Aray 2021; Luo and Wang 2021). Although CSR does not allow the organization to achieve complete legitimacy, it seems increasingly necessary when considering the expectations of Western societies (Chiu and Sharfman 2011; Garanina and Aray 2021). Thus, active CSR projects attract public attention and generate benefits to society, which enhances the company's reputation and legitimacy (Chiu and Sharfman 2011; Zhang et al. 2016; Xu and Liu 2020).

In addition to implementing strategies such as CSR, firms can also pursue legitimacy and reputation through various internal mechanisms, such as the board of directors (Hambrick and D'Aveni 1992; Daily and Schwenk 1996). Various potential benefits of boards - namely, advice and guidance on the one hand, and external legitimacy and networking on the other-are considered to be particularly valuable (Hillman and Dalziel 2003). Regarding external legitimacy and net-working, firms often hire external directors to enhance the firm's legitimacy in its environment (Zahra and Pearce 1989; Johnson et al. 1996) and to improve relations with stakeholders. Directors who are considered as community influentials, such as politicians, are especially valuable because they not only facilitate access to financial resources (Claessens et al. 2008), but also provide expertise in bureaucratic procedures (Goldman et al. 2009); specifically, they can also bring non-business perspectives that may be valued by shareholders and endow the company with legitimacy by considering the interests of other stakeholders in board discussions (García-Meca and Palacio 2018). This concern of political directors (i.e., directors with political connections) for the interests of other stakeholders has also been reflected in their support for CSR.

In recent years, the literature addressing the effect of directors' political connections on CSR has increased. Prior studies have indicated several advantages (e.g., government subsidies and resources, access to financial resources, less bureaucracy and oversight, more information and influence) derived from political presence in firms (Guerra Pérez et al. 2015; Li et al. 2015; Zhang et al. 2016; Xu and Liu 2020). However, these effects also depend on the institutional context and the specific form that the relationship between business and political connections takes (Chiu and Sharfman 2011; Bianchi et al. 2019; Yu and Chi 2021).

When referring specifically to CSR strategies, prior literature notes that political conditions may favor greater CSR. This relationship can be explained via several reasons. First, according to social exchange theory and the reciprocity principle in social relationships, governments also expect some action from those companies with political directors due to the benefits they derive from their political connections ( $\mathrm{Li}$ et al. 2015; Fernández-Gago et al. 2018; Xu and Liu 
2020). Thus, CSR may be considered as a response to government expectations to increase the welfare of society through the CSR of companies with political connections (Lin et al. 2015; Zhang et al. 2016; Wang et al. 2018; Xu and Liu 2020; Yu and Chi 2021). Thus, if the firm acts in the government's interests, the company may gain greater legitimacy (Marquis and Qian 2014; Li et al. 2015). Conversely, if these government expectations are not met, there could be a loss of legitimacy for the firm (Luo and Wang 2021).

Second, per the social view approach, which bases its arguments on the public interest theory, politicians should use resources to promote social projects or to cure market failures (Atkinson and Stiglitz 1980), since their political status may imply that they are responsible for defending public interest and improving social welfare (Wang et al. 2021). Politicians might therefore attempt to provide individuals with certain public services (e.g., through increased CSR), as they care more about society's welfare and interests (Wang et al. 2021). Third, companies with political directors are subject to more public and governmental scrutiny (Chen et al. 2017; Zhang 2017; Fernández-Gago et al. 2018; Xu and Liu 2020) and are under greater pressure to invest in CSR activities (Chiu and Sharfman 2011; Marquis and Qian 2014) as politicians are expected to have high moral standards (Zhang 2017; Xu and Liu 2020) and, thus, a special interest in CSR investment.

Finally, politically connected directors may have personal goals that CSR could allow them to achieve. As noted above, CSR attracts public attention, not only towards the company, but also towards its managers and directors (Zhang 2017; Xu and Liu 2020). In this sense, directors can use CSR as a source of entrenchment, as it favors the satisfaction of society's demands, enabling them to strengthen their position (Villarón-Peramato et al. 2018). Moreover, in contexts where politicians are viewed negatively by society because of corruption scandals (Ramón-Llorens et al. 2019), political directors may use CSR to protect their personal reputation and maintain or enhance their personal political legitimacy, which could lead to political or professional promotion (Marquis and Qian 2014; Zhang 2017; Wang et al. 2018; Luo and Wang 2021; Yu and Chi 2021).

Therefore, we propose the following hypothesis:

Hypothesis 1 The higher the percentage of political directors on the board, the greater the allocation of resources to CSR activities.

After hypothesizing the positive influence of political directors on CSR, we explore their characterization by arguing that politicians may not necessarily be a homogeneous group but may maintain different beliefs and/or identities. Here, we focus on political ideology and the regional identity of political directors. As Fernández-Gago et al. (2018) argue, we consider that directors' characteristics can have a dual impact (directly and/or moderating) on CSR. Thus, political ideology and regional identity can directly influence CSR and/or moderate the relationship between directors' political connections and CSR, making this relationship stronger or weaker. In the latter case, we suggest that although political 
directors have a positive effect on CSR, the intensity of this relationship may depend on their political ideology and regional identity.

\subsection{Liberal political ideology and CSR}

Political ideology is a key personal factor that helps to better understand "why people do what they do" (Jost 2006). Specifically, using the definition proposed by Erikson and Tedin (2003, p. 64) (also used by other authors: Jost 2006; Jost et al. 2009), ideology refers to "the set of beliefs about how to order society and how to achieve it." These personal beliefs, along with other personal variables already described in the literature (e.g., age, gender, grade and diversity of knowledge, professional expertise, etc.), influence individuals' decision-making. In addition to individuals' beliefs, psychology plays an important role in determining the factors that distinguish one ideology from another.

The most widely studied dimension of ideology differentiates liberalism from conservatism. This dimension is universal, stable, and persists during a person's lifetime and allows us to understand individual beliefs (Jost 2006; Johnson and Roberto 2019; Jeong and Kim 2020). In this sense, the literature on ideology has corroborated the existence of significant differences (cognitive, affective, and motivational) between people with a liberal ideology and those with a conservative ideology (Jost et al. 2003, 2009; Jost 2006; Carney et al. 2008).

While individuals with a conservative ideology share a greater affinity for individualism and free markets (Jost et al. 2003; Carney et al. 2008; Gupta and Wowak 2017), liberal ideology is associated with the defense of social justice, the fight against social and economic inequality, and is linked to egalitarianism and compassion (Evans et al. 1996; Jost et al. 2003; Jost 2006; Shi et al. 2019). Within the framework of a political system, these ideological beliefs are generally aligned with programs defended by political parties, which are also classified as either liberalism or conservatism. Thus, different approaches of the so-called "partisan theory" have been compared in previous empirical studies on public administration (e.g., Jensen 2010; Potrafke 2011). Liberal political parties have been shown to promote public policies in order to expand public spending (increasing indebtedness and the growth of public administration) so as to reduce inequality and achieve a fairer society (Pontusson and Rueda 2010; Potrafke 2011).

In applying this general reasoning to the corporate sphere, recent literature confirms the effect of ideology on corporate decision-making. Most of these studies focus on the CEO's ideology, while only a few analyze the ideology of the board of directors. Regarding evidence concerning CEOs and top executives, their liberalismconservatism beliefs have been associated with several corporate policies, especially company CSR (Chin et al. 2013; Di Giuli and Kostovetsky 2014; Gupta et al. 2019; Jeong and Kim 2020). Regarding the influence of board member ideology on CSR, a recent study (Jouber 2021) reports a positive influence of ideological diversity (conservatism vs. liberalism) of the board on CSR, while Di Giuli and Kostovetsky (2014) find that firms with liberal directors score higher on CSR. 
Based on the above literature, liberal ideology is consistent with an increase in a firm's CSR (Chin et al. 2013; Di Giuli and Kostovetsky 2014; Gupta et al. 2019). In this way, liberals may consider the entity's responsibility more expansively, incorporating the needs of all stakeholders, including society as a whole (Briscoe et al. 2014; Gupta et al. 2019). By promoting these CSR practices, organizations may, therefore, help to achieve a more equalitarian society and social justice (Chin et al. 2013; Gupta et al. 2019).

Considering the literature on ideology applied to both public administration and corporate firms, political directors who maintain a liberal ideology on company boards may be expected to focus greater attention on the impact of corporate policies on society. Therefore, we propose the following hypotheses:

Hypothesis 2a The higher the percentage of political directors with a liberal ideology on the board, the greater the allocation of resources to CSR activities.

Hypothesis $\mathbf{2 b}$ The percentage of political directors with a liberal ideology on the board positively moderates the relationship between political directors and CSR activities.

\subsection{Regional identity and CSR}

In addition to the ideology of political directors, the influence of another political dimension - their regional identity - on the behavior of politicians has been less studied. According to social identity theory (Tajfel and Turner 1986; Abrams and Hogg 1990), individuals modify their behavior and, therefore, their decision-making, in response to their self-conception of group membership. As Ispas (2012, p. 18) points out, "we think and act differently when we think of ourselves as a member of a particular group than when we think of ourselves as an individual."

The cornerstone of this theory is that individuals are largely defined by the social group(s) to which they belong, and that they are motivated to seek positive distinctiveness for their group to increase their self-esteem (Tajfel and Turner 1986). Since maintaining group identity is critical to an individual's self-esteem, this motivates them towards attitudes and behaviors that promote the defense of group interests (socalled in-group favoritism), sometimes at the expense of the interests of other groups (out-group discrimination) (Devine 2015; Shi and Tang 2015). In this context, social identity is what leads the individual to establish the basis of their identification with the group (Crane and Ruebottom 2011). Some well-known social identities in business studies include gender, age, race, culture, sexual orientation, and nationality (e.g., Markoczy et al. 2020; Raskovic and Takacs-Haynes 2021). Although studies addressing political-territorial identification have focused primarily on national identity based on nationality (e.g., Kaczmarek et al. 2012; Wöcke et al. 2018), a growing body of work addresses regional identity, considering it as another form of subnational identity that focuses on the individual's relationship with their local/ regional community (Lantz and Loeb 1998; Fernández-Ferrín et al. 2021). According to Raagmaa (2002, p. 58), who adapts the definition of Häuszer and Frey (1987), 
regional/local identity can be defined as "a phenomenon where people identify themselves with the social system of a certain region ...with its people, culture, traditions, landscape, etc.”. This regional identification usually coincides with the place that the individual considers to be their home (Fernández-Ferrín et al. 2021). Based on social identity, the consequence of this approach is that the stronger an individual's regional identity, the more willing they will be to act in favor of it, i.e., to make decisions that promote regional favoritism.

This effect seems to be demonstrated in the work of Fernández-Ferrín et al. (2021) on the effect of regional identity as a moderator/driver of the relationship between CSR and consumer loyalty, or in the study by Lantz and Loeb (1998) on the preference for consuming locally manufactured products. In this context, we suggest that politicians affiliated with a party that defends regionalist interests are likely to have a strong regional identity, which will lead them to promote policies that favor spending in that region through greater CSR.

To the best of our knowledge, no studies have addressed the influence of regional identity on CSR policy as an output of the firm. To date, the only evidence of regional favoritism that we've found associates politicians' regional identity with their hometown. These studies generally analyze whether politicians promote regional favoritism through increased public funding (Fiva and Halse 2016), investment in roads (Burgess et al. 2015), boosting economic activity (measured through more intense nighttime light) (Hodler and Raschky 2014), or, in the corporate sphere, through (over)investment (Chen et al. 2020; Guo et al. 2021). As mentioned before, all these studies approach regional identity through politicians' hometowns. Although valid, this approach assumes that an individual maintains intrinsic favoritism for a region because they were born or raised there. A more accurate way to measure this regional identity is to list whether the politician is affiliated with a political party that defends regional interests. We consider that this regional identity can also be approached through its affiliation with a regionalist party.

Regionalist parties focus on recognizing regional peculiarities or allocating power and resources to the region (De Winter and Türsan 1998; Massetti and Schakel 2015). Along these lines, regionalist parties in developed countries tend to boost social expenditure in their territories, regardless of whether they are liberal or conservative. The justification for this increased spending is that it helps build and consolidate a regional/local identity (Beland and Lecours 2008; Mooney and Scott 2011). In this sense, Jacobsen's (2006) study of a sample of 30 Norwegian municipalities determined that the greater a regional politician's sentiment, the greater the spending preferences.

Therefore, despite the scarce empirical evidence, we consider that these theoretical arguments allow us to support the thesis concerning the influence of political directors' regional identity on CSR policy. Specifically, we propose that political directors who exhibit regional identity could favor company-spending resources in the territory with which they identify (regional favoritism). Therefore, we hypothesize the following: 
Hypothesis 3a The higher the percentage of political directors with a regional identity on the board, the greater the allocation of resources to CSR activities.

Hypothesis $\mathbf{3 b}$ The percentage of political directors with a regional identity on the board positively moderates the relationship between political directors and CSR activities.

\section{Institutional framework}

This study analyzes the political connections, ideology, and regional identity of directors of cajas, operated in Spain from 2004 to 2013. Cajas were a fundamental part of the Spanish financial system since they first appeared in the nineteenth century (Caja de Ahorros de Jerez de la Frontera was the first to be founded in 1834) until their virtual disappearance over the last decade. Currently, only two entities maintain the legal form of caja: Caja de Ahorros de Pollença "Colonya" and Caja de Ahorros and Monte de Piedad de Ontinyent. Their importance is reflected in the more than 21,000 branches that the cajas owned in their entirety at the beginning of 2000 , or in their market share in deposits higher than that of commercial banks (55\% of the market).

Cajas feature unique characteristics that distinguish them from other financial entities, such as commercial banks or credit cooperatives. First, they originally focused on promoting savings, although in their later stages, they also entered the loans and mortgages market. In addition, originally, their activities focused on a certain geographical area (typically, a province), although since the deregulation introduced by the Royal Decree 1582/1988, most cajas followed a policy of geographical expansion throughout most of the country. Legally, cajas are private (non-public) entities without owners; in other words, they do not have residual property rights holders (García-Meca 2016). Consequently, there is no profit distribution. In contrast, part of the annual profits is dedicated to CSR activities through so-called social work (obra social), i.e., projects of a cultural, social, educational, or artistic conservation nature. However, despite the absence of property rights, regulation established the distribution of control rights among various groups of stakeholders (depositors, public administrations, employees, founders, and entities of general interest), which constituted the governing bodies of each caja: general assembly, board of directors, and control committee. Among these governing bodies, the board, which oversaw the effective administration and management of the caja, played an important role. Thus, its composition is the focus of our analysis.

For several reasons, these entities are especially interesting for testing our hypotheses. First, successive legislation gave public administrations the role of the dominant group in the cajas' governance system (García-Cestona and Surroca 2008; Andres et al. 2021). In this way, the presence of directors with political connections was quantitatively important and explains why prior literature on cajas' governance has focused on the consequences of politicization, given its 
role as a key stakeholder. Most previous studies have considered the effects of politicization on cajas' performance (Azofra and Santamaría 2004; García-Meca and Sánchez-Ballesta 2014; Andres et al. 2021), while few have analyzed its impact on CSR (e.g., López Iturriaga et al. 2007).

Second, according to the annual report of the Spanish Confederation of Savings Banks (CECA), the resources allocated to CSR progressively increased until they reached their maximum in 2007 (1952 million euros), at which point the crisis and the restructuring of the sector caused their decline. In fact, cajas' CSR was one of the hallmarks that set them apart from commercial banks so they promoted and expanded their CSR activity to contrast this "social dividend" against the private dividend of commercial banks, which contributed to their success (Gomez-Carrasco et al. 2016).

Third, the importance of cajas in the Spanish financial system as well as the presence of politicians on their boards gave them greater visibility, which meant that their legitimation pressures were higher (Chiu and Sharfman 2011). As the dominant stakeholders, public administrations were responsible for guaranteeing the allocation of resources to public goals (García-Cestona and Surroca 2008). Thus, while directors designated by other stakeholders had to defend their respective interests (e.g., employees, depositors), the political directors who represented public administrations had to defend society's interests, which corresponds with CSR. In this way, these directors did not play the same role as companies' independent directors with political ties, because in the case of cajas, their appointment depended on the public administration they represented.

Fourth, the reputation of politicians and political parties in Spain has declined since the turn of the century, as demonstrated by the 15M Movement in 2011, characterized by dissatisfaction with the political system (Hughes 2011). This is also reflected in the barometer of the Spanish Center for Sociological Research (CIS), which showed how the political class and political parties were the third main problem in the country in January 2011 (after unemployment and economic problems). Therefore, the context is one in which political connections are viewed with suspicion (Ramón-Llorens et al. 2019), which may lead to more investment in CSR, given that cajas were forced to demonstrate that, despite this political presence, they met society's expectations (Bianchi et al. 2019). Similarly, political directors, whose personal reputation was damaged, could view CSR as an appropriate strategy to improve their reputation in order to achieve personal goals.

Finally, Spain's sociological and political situation, where regional identity has expanded in various areas, allows us to analyze the characteristics of political directors. In this way, political directors from regions such as the Basque Country, Catalonia, or Galicia, where regional identity is deeply rooted, may have a strong regional sentiment that conditions their behavior. This strong regional identity is reflected, for example, in the CIS barometer, which demonstrated in 2011 that, contrary to the national average, most of the population in these regions felt they had more in common with people from the same region but at a different social level than with people of the same social level but from other regions. 


\section{Sample, model, variables, and methodology}

\subsection{Sample}

Our sample consists of 45 Spanish cajas for the period 2004-2013 (304 observations). Information concerning the composition of the boards of directors was extracted from the annual CECA report and the annual corporate governance report of each caja. After identifying the board members, we built a custom database to record the political affiliation of each director (regardless of the interest group they represented in the caja), determined by searching through different sources of information (web pages of political parties, municipalities, county councils, autonomous regions, and official regional gazettes in which the electoral lists appear in the different calls for national and regional elections). Ultimately, we examined the political affiliations of 1578 directors. Specifically, we analyzed whether each director had (or previously had) a clear link with a political party, either by holding a public office representing the party or by appearing in their electoral lists. Although not all individuals manifest their ideology/identity through party affiliation, an individual's political party affiliation is considered a stable and accurate proxy for their political ideology (Goren et al. 2009; Johnson and Roberto 2019) or identity (Finkel and Scarrow 1985; Greene 1999). In addition, directors with political affiliations represented, on average, most board directors $(52 \%)$.

Once each director's affiliation to a specific political party was determined, we characterized their ideology and identity according to the two dimensions established in the study: the one related to liberalism, and the other referring to regionalism. To this end, based upon Massetti and Schakel's (2015) study, we classified each political party as liberal and/or regionalist, as shown in Table 5 in the "Appendix". To determine the ideology of the parties not included in Massetti and Schakel's study (2015), we relied on the information on their website as well as their statutes. Economic-financial information was obtained from annual CECA reports.

\subsection{Model, variables, and methodology}

Our model to test our hypotheses is the following:

$$
\begin{aligned}
& \text { CAJAS' CSR }_{\text {it }}=\beta_{0}+\beta_{1} \text { POLITICIAN }_{i t}+\beta_{2} \text { LIBERAL }_{i t}+\beta_{3} \text { REGIONALIST }_{i t}
\end{aligned}
$$

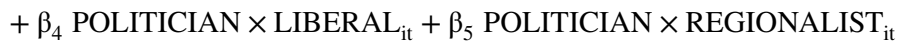

$$
\begin{aligned}
& +\beta_{6} \text { CONTROL VARIABLES }_{\mathrm{it}}+\mathrm{d}_{\mathrm{t}}+\varepsilon_{\mathrm{it}}
\end{aligned}
$$

where $i$ identifies the caja, $t$ the year, $d_{t}$ the time effect, and $\varepsilon_{i t}$ the random disturbance.

Our dependent variable to test our hypotheses is the amount allocated to the CSR (obra social) of the caja (cultural, educational, social projects, etc.) divided by the net profit of the entity (CSR variable) (López Iturriaga et al. 2007; Cabeza-García et al. 2010). We disaggregate this general variable into the four categories reported by CECA, all divided by net profits: culture (CSR_CULTURE), health and social 
assistance (CSR_HEALTH), education and research projects (CSR_EDUCATION), and historical, artistic, and natural heritage (CSR_HERITAGE).${ }^{4}$ We winsorized all variables to avoid the influence of outliers (Zhang et al. 2016).

In terms of political ties, we use the proportion of those representing local and regional governments or those affiliated with a political party (POLITICIAN) (Andres et al. 2021). Regarding political ideology, we use the proportion of politicians linked to liberal political parties (LIBERAL). As for regional identity, we use the proportion of political directors linked to regionalist political parties (REGIONALIST). We also built three variables to differentiate between directors with a liberal ideology and a regional identity (LIBERAL_REGIONALIST), a liberal ideology but no regional identity (LIBERAL_NONREGIONALIST), and a regional identity but no liberal ideology (REGIONALIST_NONLIBERAL).

Finally, following prior literature on CSR and banking, we add several control variables related to the board, the caja, and the region in which the caja was constituted. Regarding the board of directors, we include the logarithm of the size of the board of directors (BOARD_SIZE), whose expected effect is not defined, since both positive and negative impacts could be justified (Fernández-Gago et al. 2018; $\mathrm{Yu}$ and Chi 2021); the diversity of educational background on the board (EDUCATION), measured with a Blau index $\left(1-\sum\left(\mathrm{P}_{\mathrm{i}}\right)^{2}\right)$ considering seven branches of knowledge and whose expected impact is positive (Fernández-Gago et al. 2018); and the proportion of women on the board (GENDER), whose effect is expected to be positive (Cabeza-García et al. 2018; Wang et al. 2021). We also include variables related to the caja, including its size measured using the logarithm of its total assets (SIZE), with an expected positive effect on CSR (Lin et al. 2015; Yu and Chi 2021); a measure of performance, such as the return on equity (ROE), whose effect we expect to be positive ( $\mathrm{Li}$ et al. 2015); the Capital Adequacy Ratio (CAR), which can be used as a measure of solvency (Andres et al. 2021) and whose expected effect is negative, as higher indebtedness is positively related to CSR (Wang et al. 2018; $\mathrm{Xu}$ and Liu 2020); a measure of the caja's business structure (GAP), measured as total loans to clients divided by total deposits to clients (Cardone-Riportella et al. 2010), and whose expected sign is not defined; credit risk, measured as the amount allocated to nonperforming loans divided by total loans to clients (CREDIT_RISK) (Andres et al. 2021), whose effect we expect to be negative, since if the caja has credit problems, fewer resources will be allocated to CSR; and the geographical extension of the caja's business, measured as the number of different Spanish regions in which the caja has offices (REGION_OFFICES), whose expected effect is positive, given that if the caja is located in more regions, it will have to invest and satisfy the demands in each of them. Finally, regarding the region in which the caja was constituted, we include GDP per capita in that region (REGION_GDP), and expect a positive effect (Xiang et al. 2021), and dummy ELECTIONS, which record " 1 " in those years in which there were elections in that region, and whose effect we expect to be positive since CSR could be used for electoral purposes (Dinç 2005). All these variables are defined in Table 6 of the "Appendix".

\footnotetext{
${ }^{4}$ The disaggregation of CSR into project categories was only published up to 2010, hence only 296 observations are available in the estimations with this variable.
} 
Given the structure of our sample, we used a panel data methodology to test our hypotheses. Although the endogeneity problem that usually arises in governance variables is more limited in our model than in others (since the appointment of political directors follows a legal criterion rather than reasons of economic efficiency), we use the generalized method of moments (GMM) (Arellano and Bover 1990; Bond 2002). Specifically, we use the two-step system GMM estimator with adjusted standard errors for potential heteroscedasticity (Blundell and Bond 2000). This technique allows us to control for constant unobserved heterogeneity and contend with possible endogeneity among variables (Blundell and Bond 2000; Bond 2002). To capture the influence of past data on the current data, we include two lags of the independent variables that are potentially endogenous. However, we collapsed the instruments to avoid instrument proliferation.

To test the model specification validity, we report the variance inflation factor (VIF) to verify that there are no multicollinearity problems in the models (all the estimations have a value below 2.5); the Hansen test of over-identifying restrictions to check the validity of the selected instruments; the $\mathrm{m} 2(\mathrm{AR}(2))$ to test the absence of second-order serial autocorrelation in the estimations; and two Wald tests for the joint significance of the reported coefficients (z1) and for the time dummy variables (z2).

To test the moderating role of liberal and regionalist politicians, we use standardized data and introduce the interaction terms in the model (POLITICIAN $\times$ LIBERAL and POLITICIAN $\times$ REGIONALIST). All estimations were calculated using STATA statistical software.

\section{Results}

\subsection{Descriptive statistics}

Table 1 shows the sample information using the descriptive statistics of all variables indicated above.

As presented in Table 1, cajas allocated one-third of their net benefit to CSR activities (33\%), which is higher than the value shown by Cabeza-García et al. (2010) for the period 1992-2005. Specifically, cajas invested the most in culture (15\% of the net benefit), followed by health $(9 \%)$, education $(6 \%)$, and heritage (3\%). These figures have a similar pattern to that obtained by López Iturriaga et al. (2007) for 2004.

On average, $52 \%$ of boards had political ties (POLITICIAN). When observing the minimum value (17\%), we can confirm that all cajas had directors with political connections, as the legislation always granted public administration representation. According to our data, $41 \%$ of these political directors maintained a liberal ideology (LIBERAL), although we found extreme cases in which cajas had no liberals on their boards (e.g., Bilbao Bizkaia Kutxa, La Caixa, Caixa D'Estalvis de Sabadell) and others where all their political directors display a 


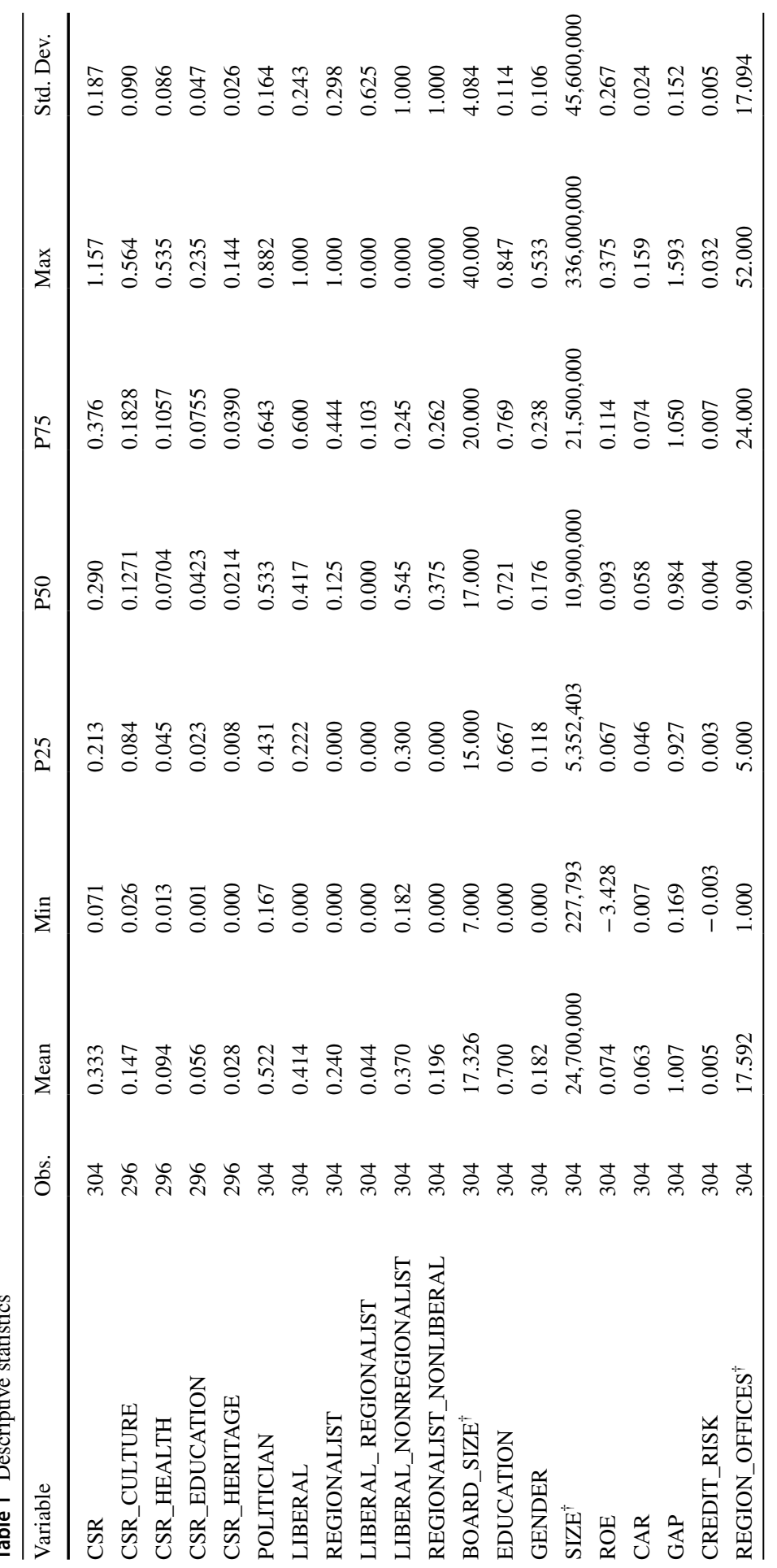




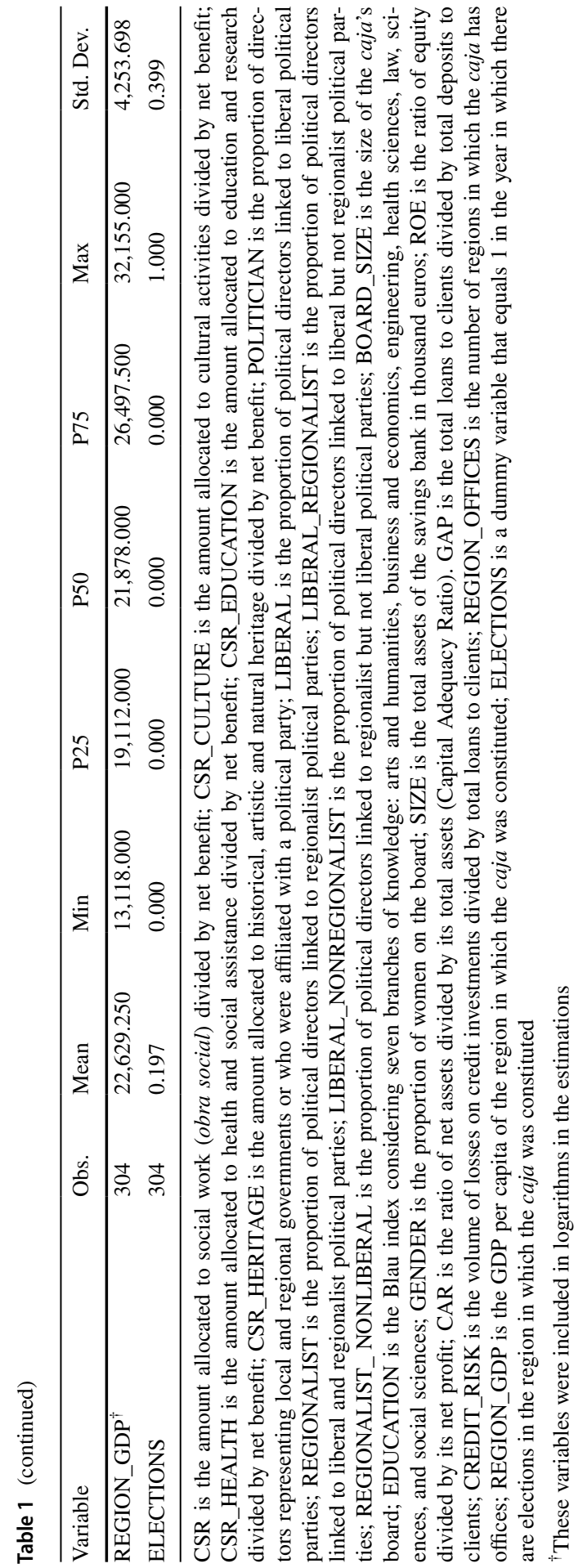


liberal ideology (e.g., Caixa D’Estalvis de Terrassa, Caja de Ahorro Provincial de Guadalajara). In terms of regional identity, we find lower figures, as, on average, $24 \%$ of political directors were considered regionalists. However, at least $25 \%$ of the sample had no political directors with this regional identity on their boards (e.g., Caja de Ahorros y Monte de Piedad de Madrid, Caja de Ahorros de Asturias, Caja de Ahorros del Mediterráneo). Nevertheless, we also find various cajas in which all (or most) of their political directors are regionalists (e.g., Bilbao Bizkaia Kutxa, Caixa d'Estalvis del Penedès).

\subsection{Explanatory analysis}

Table 2 presents the results of the estimations related to CSR policy. As presented in the table, all variables have been included step by step, beginning with the control variables (Model 1), consecutively followed by new ones: (1) the direct effect of politicians, regardless of their ideology and social identity, on CSR (Model 2); (2) the direct effect of liberal politicians and their interaction with other politicians (Models $3 \mathrm{a}$ and $3 \mathrm{~b}$ ); (3) the direct effect of regionalist politicians and their interactions with other politicians (Models 4a and 4b); and (4) the direct effects of politicians, liberals, and regionalists, as well as the interactions between them (Models 5a and 5b).

For control variables, we find that the caja's performance (ROE), the number of regions in which the caja has offices (REGION_OFFICES), and the level of wealth of the region in which the caja was established (REGION_GDP) have a positive coefficient with the dependent variable in a number of models. Similar results can be found in Li et al. (2015) and Xiang et al. (2021) for performance and regional wealth, respectively. Therefore, they all have a positive influence on the percentage of net profit that the caja allocates to CSR. In contrast, the capital assets ratio (CAR) is negatively related to the caja's CSR [comparable results can be found in Wang et al. (2018) and $\mathrm{Xu}$ and Liu (2020)]. Moreover, the variable that measures the business structure of the caja (GAP) also shows negative coefficients, which means that if the entity is more dedicated to granting loans than to receiving deposits, the proportion of net profit allocated to CSR was lower. The volume of the caja's assets (SIZE) also shows a negative coefficient in Model 1, i.e., larger cajas allocate a smaller percentage of their profits to CSR, which runs contrary to the expected sign. However, this variable is no longer significant in most of the remaining models. Finally, none of the control variables related to the board (BOARD_SIZE, EDUCATION, and GENDER) demonstrated a significant influence on CSR, indicating that the most relevant characteristic of the caja's boards in terms of CSR is their politicization.

When introducing the variable that measures board politicization in the model (see Model 2), we find that the more political directors on the caja's board (POLITICIAN), the greater the amount spent by the caja on CSR activities, thereby confirming Hypothesis 1. Thus, regardless of the ideology or social identity of politicians on the board, they are always in favor of increasing the caja's social activity.

Having tested the relevance of political connections on CSR, we introduce directors' political ideology (LIBERAL) and regional identity (REGIONALIST) into the 


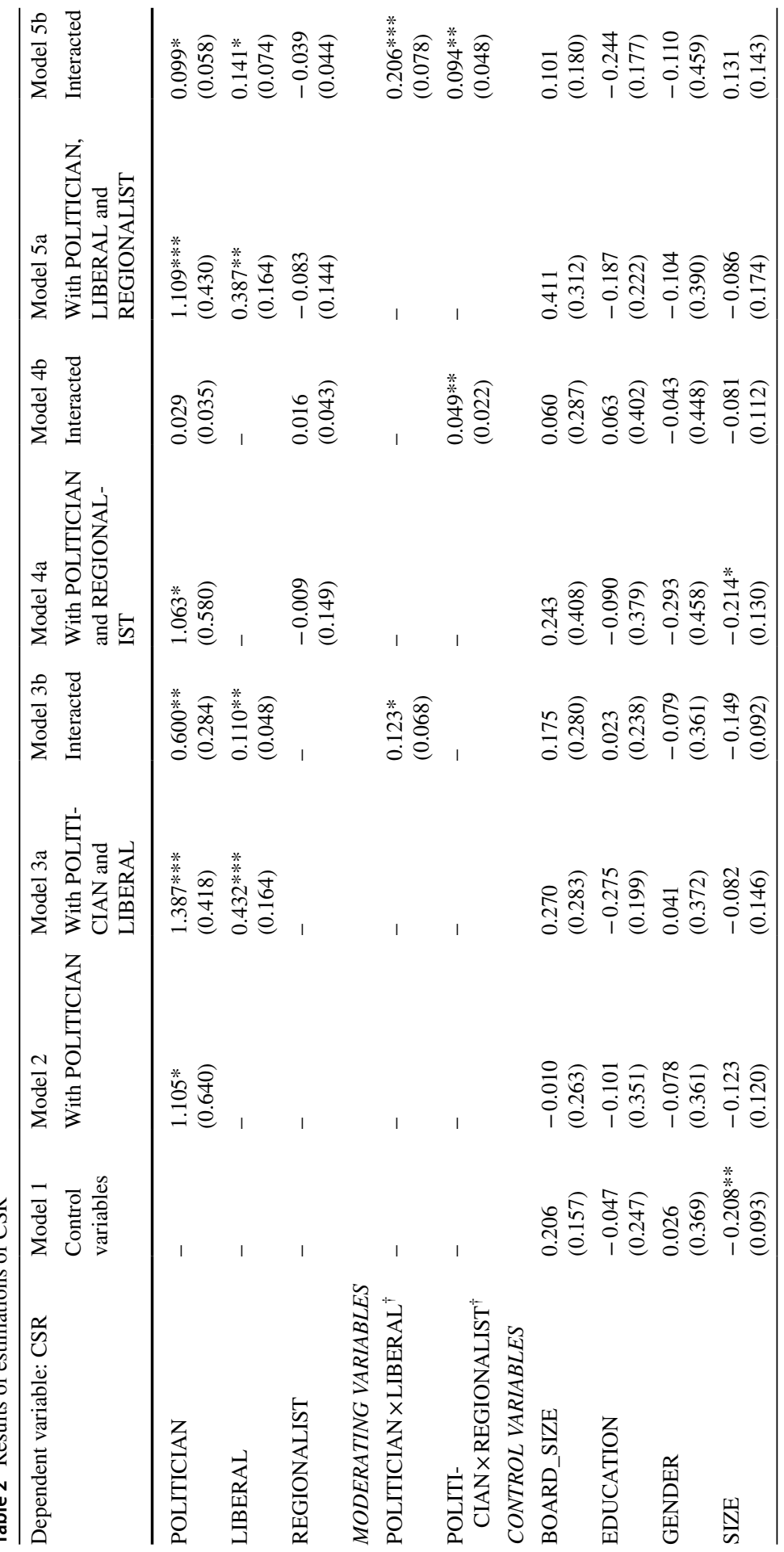




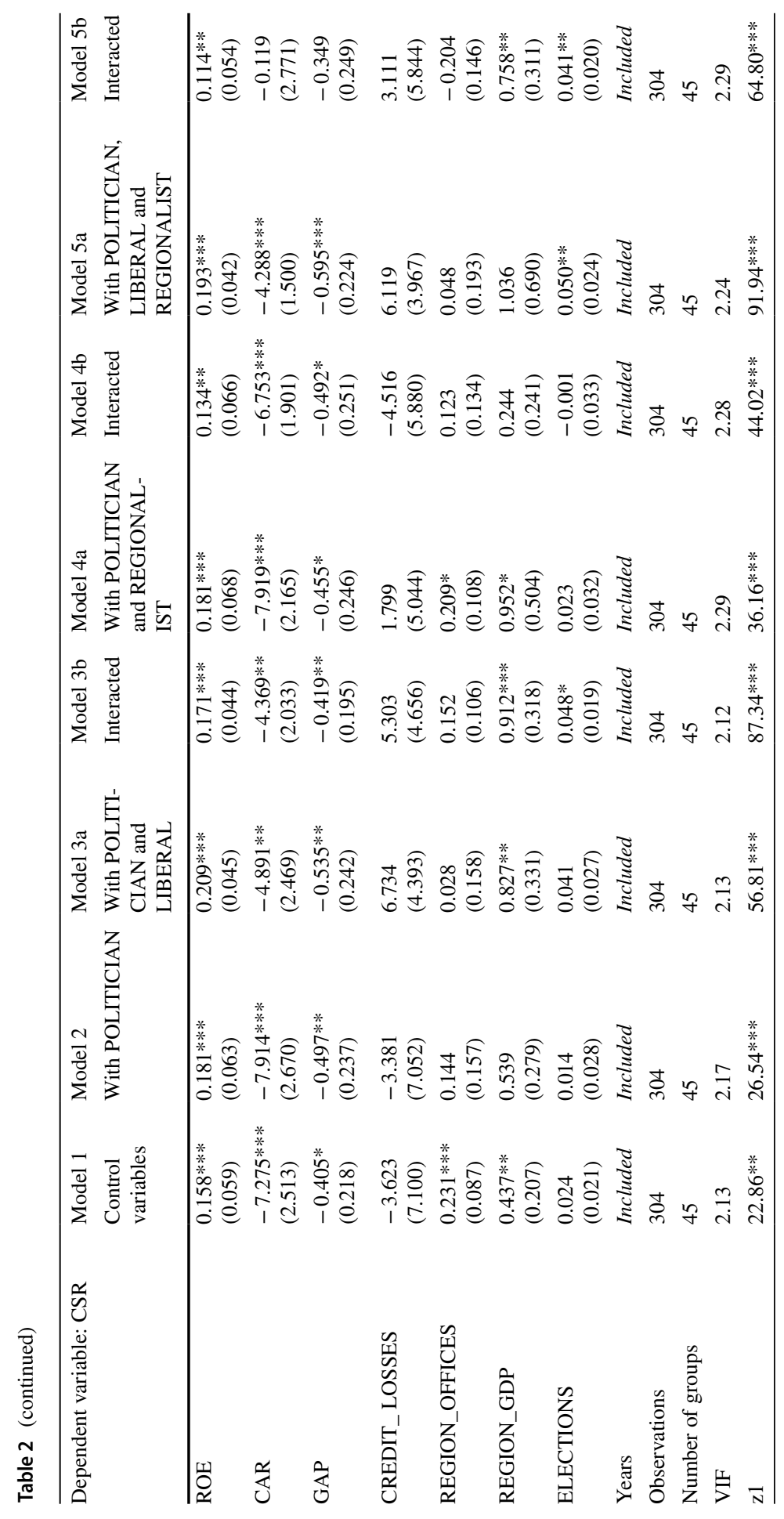




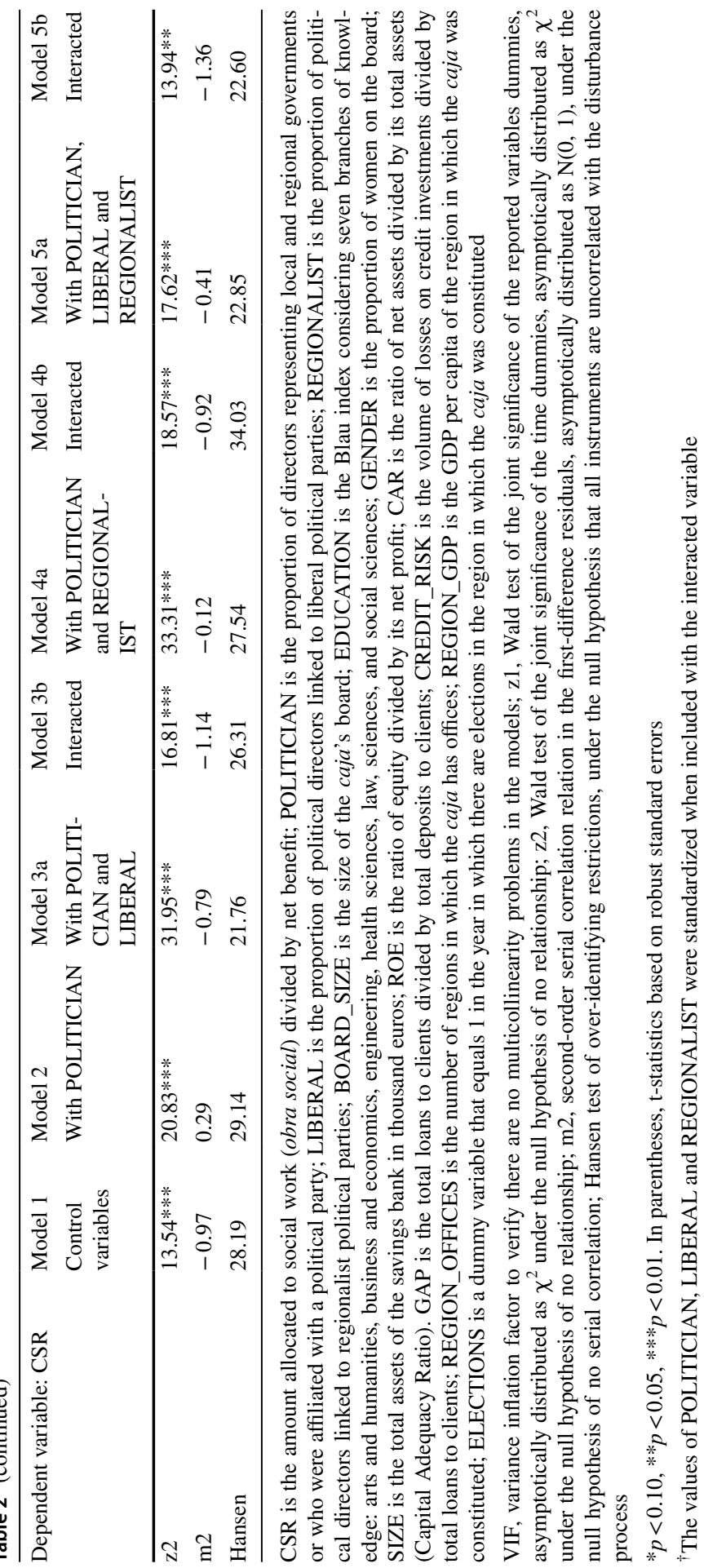


model. According to our hypotheses, both issues may directly and indirectly influence CSR. Hence, we test the different effects in Model 3 (for liberal politicians), Model 4 (for regionalist politicians), and Model 5 (for liberal and regionalist politicians). As can be seen, the percentage of political directors with a liberal ideology has a direct influence on CSR, which implies that the higher the proportion of political directors with a liberal ideology, the greater the caja's CSR (Model 3a). However, our results also indicate that they have the ability to boost politicians' positive effect on CSR (see the positive coefficient of the interaction variable); that is, this effect is stronger as the percentage of liberal political directors increases (Model 3b). These results support Hypotheses $2 \mathrm{a}$ and $2 \mathrm{~b}$ and indicate a quasi-moderation effect.

The presence of politicians with a regional identity on the board proves to be significant only when referring to the interaction variable. This result supports a pure moderation effect of regionalist political directors because the percentage of politicians with a regional identity does not have a direct influence on the caja's CSR (Model 4a), although regionalist political directors reinforce the role of politicians in favoring CSR (see the positive sign of the interaction coefficient in Model 4b). Thus, we rejected Hypothesis $3 \mathrm{a}$, but supported Hypothesis $3 \mathrm{~b}$.

Finally, when we include all variables in a single final model (Models 5a and 5b), we observe that all previously described results are maintained. In these models, it is interesting to note the significance of the election variable (ELECTIONS), which has a positive sign, indicating that during election years, the percentage of profits devoted to social work increases. This result corresponds with previously proposed arguments concerning the use of cajas' CSR by politicians for their own benefit (i.e., for self-legitimization, especially during election periods). The results can also be explained using arguments related to political patronage (Piattoni 2001), such as clientelism and pork barrel politics, since this implies the use of funds to favor specific public projects in exchange for securing a strong status within the political party or obtaining voter support for re-election.

\subsection{Additional analyses}

To further explore the relationship between the politicization of cajas' boards and their CSR, we analyze their influence on the percentage of CSR allocated to the different activities reported by CECA—culture, health and social assistance, education and research projects, and natural and artistic heritage (see Table 3). When analyzing these results, we observe that the direct and indirect effects of the presence of liberals on the cajas' boards remain when we refer to the activities to which most of the cajas' funds are devoted to-culture and health (Model 1 and Model 2). In addition, the regionalist enhancing effect on the relationship between political directors and CSR is maintained.

However, when we focus on CSR aimed at education or heritage, we observe different behaviors when discussing liberal ideology or regional identity. A direct effect of politicians with a liberal ideology is found when analyzing the percentage of benefits allocated to heritage, while in the case of regionalists, their indirect influence is manifest when the percentage of benefits aimed at education is examined. These 
Table 3 Results of CSR estimations divided into activities

\begin{tabular}{|c|c|c|c|c|}
\hline & $\begin{array}{l}\text { Model } 1 \\
\text { CSR_CULTURE }\end{array}$ & $\begin{array}{l}\text { Model } 2 \\
\text { CSR_HEALTH }\end{array}$ & $\begin{array}{l}\text { Model } 3 \\
\text { CSR_EDUCATION }\end{array}$ & $\begin{array}{l}\text { Model } 4 \\
\text { CSR_HERITAGE }\end{array}$ \\
\hline POLITICIAN & $\begin{array}{l}-0.057 \\
(0.040)\end{array}$ & $\begin{array}{l}0.015 \\
(0.056)\end{array}$ & $\begin{array}{l}-0.010 \\
(0.021)\end{array}$ & $\begin{array}{l}-0.003 \\
(0.013)\end{array}$ \\
\hline LIBERAL & $\begin{array}{l}0.041 * \\
(0.023)\end{array}$ & $\begin{array}{l}0.047^{*} \\
(0.028)\end{array}$ & $\begin{array}{l}0.016 \\
(0.014)\end{array}$ & $\begin{array}{l}0.025^{*} \\
(0.013)\end{array}$ \\
\hline REGIONALIST & $\begin{array}{l}-0.048 \\
(0.060)\end{array}$ & $\begin{array}{l}0.002 \\
(0.038)\end{array}$ & $\begin{array}{l}-0.024 \\
(0.025)\end{array}$ & $\begin{array}{l}-0.011 \\
(0.010)\end{array}$ \\
\hline \multicolumn{5}{|l|}{ MODERATING VARIABLES } \\
\hline POLITICIAN $\times$ LIBERAL $^{\dagger}$ & $\begin{array}{l}0.131 * * \\
(0.055)\end{array}$ & $\begin{array}{l}0.103 * * * \\
(0.037)\end{array}$ & $\begin{array}{l}0.042 \\
(0.037)\end{array}$ & $\begin{array}{l}0.036 \\
(0.023)\end{array}$ \\
\hline $\begin{array}{l}\text { POLITI- } \\
\text { CIAN } \times \text { REGIONALIST }^{\dagger}\end{array}$ & $\begin{array}{l}0.166 * * * \\
(0.063)\end{array}$ & $\begin{array}{l}0.077^{*} \\
(0.041)\end{array}$ & $\begin{array}{l}0.086^{*} \\
(0.048)\end{array}$ & $\begin{array}{l}-0.012 \\
(0.017)\end{array}$ \\
\hline \multicolumn{5}{|l|}{ CONTROL VARIABLES } \\
\hline BOARD_SIZE & $\begin{array}{l}0.213 \\
(0.188)\end{array}$ & $\begin{array}{l}0.119 \\
(0.133)\end{array}$ & $\begin{array}{l}0.198 \\
(0.134)\end{array}$ & $\begin{array}{l}0.014 \\
(0.069)\end{array}$ \\
\hline EDUCATION & $\begin{array}{l}-0.074 \\
(0.119)\end{array}$ & $\begin{array}{l}0.062 \\
(0.124)\end{array}$ & $\begin{array}{l}-0.034 \\
(0.058)\end{array}$ & $\begin{array}{l}-0.007 \\
(0.056)\end{array}$ \\
\hline GENDER & $\begin{array}{l}0.031 \\
(0.290)\end{array}$ & $\begin{array}{l}-0.110 \\
(0.169)\end{array}$ & $\begin{array}{l}0.089 \\
(0.148)\end{array}$ & $\begin{array}{l}-0.111 \\
(0.076)\end{array}$ \\
\hline SIZE & $\begin{array}{l}-0.012 \\
(0.074)\end{array}$ & $\begin{array}{l}0.007 \\
(0.054)\end{array}$ & $\begin{array}{l}0.016 \\
(0.038)\end{array}$ & $\begin{array}{l}0.033^{*} \\
(0.019)\end{array}$ \\
\hline ROE & $\begin{array}{l}0.034 \\
(0.050)\end{array}$ & $\begin{array}{l}0.021 \\
(0.038)\end{array}$ & $\begin{array}{l}0.019 \\
(0.021)\end{array}$ & $\begin{array}{l}0.002 \\
(0.008)\end{array}$ \\
\hline CAR & $\begin{array}{l}-2.455^{* *} \\
(1.017)\end{array}$ & $\begin{array}{l}-1.678 \\
(1.178)\end{array}$ & $\begin{array}{l}-1.359^{* * *} \\
(0.644)\end{array}$ & $\begin{array}{l}0.567 \\
(0.450)\end{array}$ \\
\hline GAP & $\begin{array}{l}-0.004 \\
(0.122)\end{array}$ & $\begin{array}{l}0.038 \\
(0.125)\end{array}$ & $\begin{array}{l}0.004 \\
(0.061)\end{array}$ & $\begin{array}{l}-0.051 \\
(0.035)\end{array}$ \\
\hline CREDIT_LOSSES & $\begin{array}{l}-2.693 \\
(3.049)\end{array}$ & $\begin{array}{l}-3.259 \\
(2.304)\end{array}$ & $\begin{array}{l}-2.692^{*} \\
(1.595)\end{array}$ & $\begin{array}{l}-0.715 \\
(1.042)\end{array}$ \\
\hline REGION_OFFICES & $\begin{array}{l}-0.126 \\
(0.111)\end{array}$ & $\begin{array}{l}-0.071 \\
(0.054)\end{array}$ & $\begin{array}{l}-0.094 \\
(0.058)\end{array}$ & $\begin{array}{l}-0.030 \\
(0.026)\end{array}$ \\
\hline REGION_GDP & $\begin{array}{l}0.310 \\
(0.218)\end{array}$ & $\begin{array}{l}0.302^{* * *} \\
(0.111)\end{array}$ & $\begin{array}{l}0.144 \\
(0.095)\end{array}$ & $\begin{array}{l}0.116^{*} \\
(0.060)\end{array}$ \\
\hline ELECTIONS & $\begin{array}{l}-0.005 \\
(0.014)\end{array}$ & $\begin{array}{l}-0.004 \\
(0.007)\end{array}$ & $\begin{array}{l}0.002 \\
(0.007)\end{array}$ & $\begin{array}{l}0.002 \\
(0.003)\end{array}$ \\
\hline Years & Included & Included & Included & Included \\
\hline Observations & 296 & 296 & 296 & 296 \\
\hline Number of groups & 45 & 45 & 45 & 45 \\
\hline VIF & 2.25 & 2.25 & 2.25 & 2.25 \\
\hline $\mathrm{z} 1$ & $25.96^{*}$ & $65.08 * * *$ & $35.39 * * *$ & $39.54 * * *$ \\
\hline $\mathrm{z} 2$ & $15.39 * * *$ & $16.61 * * *$ & $15.98 * * *$ & $10.38^{*}$ \\
\hline $\mathrm{m} 2$ & -1.59 & -1.15 & -0.33 & -1.15 \\
\hline Hansen & 15.66 & 12.51 & 10.57 & 14.01 \\
\hline
\end{tabular}


Table 3 (continued)

CSR_CULTURE is the amount allocated to cultural activities divided by net benefit; CSR_HEALTH is the amount allocated to health and social assistance divided by net benefit; CSR_EDUCATION is the amount allocated to education and research divided by net benefit; CSR_HERITAGE is the amount allocated to historical, artistic and natural heritage divided by net benefit; POLITICIAN is the proportion of directors representing local and regional governments or who were affiliated with a political party; LIBERAL is the proportion of political directors linked to liberal political parties; REGIONALIST is the proportion of political directors linked to regionalist political parties; BOARD_SIZE is the size of the caja's board; EDUCATION is the Blau index considering seven branches of knowledge: arts and humanities, business and economics, engineering, health sciences, law, sciences, and social sciences; GENDER is the proportion of women on the board; SIZE is the total assets of the savings bank in thousand euros; ROE is the ratio of equity divided by its net profit; CAR is the ratio of net assets divided by its total assets (Capital Adequacy Ratio). GAP is the total loans to clients divided by total deposits to clients; CREDIT_RISK is the volume of losses on credit investments divided by total loans to clients; REGION_OFFICES is the number of regions in which the caja has offices; REGION_GDP is the GDP per capita of the region in which the caja was constituted; ELECTIONS is a dummy variable that equals 1 in the year in which there are elections in the region in which the caja was constituted

VIF, variance inflation factor to verify there are no multicollinearity problems in the models; $\mathrm{z} 1$, Wald test of the joint significance of the reported coefficients, asymptotically distributed as $\chi^{2}$ under the null hypothesis of no relationship; z2, Wald test of the joint significance of the time dummies, asymptotically distributed as $\chi^{2}$ under the null hypothesis of no relationship; $\mathrm{m} 2$, second-order serial correlation relation in the first-difference residuals, asymptotically distributed as $\mathrm{N}(0,1)$, under the null hypothesis of no serial correlation; Hansen test of over-identifying restrictions, under the null hypothesis that all instruments are uncorrelated with the disturbance process

$* p<0.10, * * p<0.05, * * * p<0.01$. In parentheses, t-statistics based on robust standard errors

${ }^{\dagger}$ The values of POLITICIAN, LIBERAL and REGIONALIST were standardized when included with the interacted variable

results correspond with previous studies in the field of public administration, which demonstrate that politicians of different ideologies have differing priorities when deciding on which social expenditures to allocate the public budget (e.g., Toubeau and Vampa 2021).

In this sense, while the first two models could be considered a robustness analysis with respect to the results obtained in the global model, the last two models reflect the different interests that politicians may have, and which are reflected in the type of activity they support more intensely.

Finally, because politicians with a liberal ideology may simultaneously have a regional identity, we question what the net effect of political directors could be when different ideologies and identities are mixed. Thus, we construct three different variables to identify those board members with a liberal political ideology and a regional identity (LIBERAL_REGIONALIST), those with a liberal ideology but no regional identity (LIBERAL_NONREGIONALIST), and those with a regional identity but no liberal ideology (REGIONALIST_NONLIBERAL). As presented in Table 4, the results indicate that there is a CSR-enhancing effect only in those cases where the directors are liberal (whether or not they have a regional identity). This suggests that ideology has a more significant influence in determining cajas' CSR. 
Table 4 Results of estimations of CSR dividing political directors

\begin{tabular}{|c|c|}
\hline Dependent variable & CSR \\
\hline POLITICIAN & $\begin{array}{l}0.058 \\
(0.073)\end{array}$ \\
\hline LIBERAL_REGIONALIST & $\begin{array}{l}0.073 \\
(0.081)\end{array}$ \\
\hline LIBERAL_NONREGIONALIST & $\begin{array}{l}0.043 \\
(0.068)\end{array}$ \\
\hline REGIONALIST_NONLIBERAL & $\begin{array}{l}-0.041 \\
(0.092)\end{array}$ \\
\hline \multicolumn{2}{|l|}{ MODERATING VARIABLES } \\
\hline 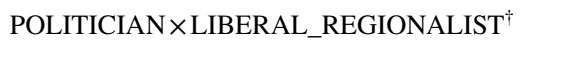 & $\begin{array}{l}0.137 * * \\
(0.063)\end{array}$ \\
\hline POLITICIAN $\times$ LIBERAL_NONREGIONALIST ${ }^{\dagger}$ & $\begin{array}{l}0.194 * * \\
(0.093)\end{array}$ \\
\hline POLITICIAN $\times$ REGIONALIST_NONLIBERAL ${ }^{\dagger}$ & $\begin{array}{l}0.051 \\
(0.283)\end{array}$ \\
\hline \multicolumn{2}{|l|}{ CONTROL VARIABLES } \\
\hline BOARD_SIZE & $\begin{array}{l}-0.055 \\
(0.600)\end{array}$ \\
\hline EDUCATION & $\begin{array}{l}-0.236 \\
(0.232)\end{array}$ \\
\hline GENDER & $\begin{array}{l}-0.029 \\
(0.633)\end{array}$ \\
\hline SIZE & $\begin{array}{l}0.004 \\
(0.095)\end{array}$ \\
\hline ROE & $\begin{array}{l}0.139 * \\
(0.072)\end{array}$ \\
\hline CAR & $\begin{array}{l}-4.735 \\
(3.754)\end{array}$ \\
\hline GAP & $\begin{array}{l}-0.284 \\
(0.332)\end{array}$ \\
\hline CREDIT_LOSSES & $\begin{array}{l}-0.617 \\
(8.915)\end{array}$ \\
\hline REGION_OFFICES & $\begin{array}{l}-0.012 \\
(0.220)\end{array}$ \\
\hline REGION_GDP & $\begin{array}{l}0.725^{* * *} \\
(0.291)\end{array}$ \\
\hline ELECTIONS & $\begin{array}{l}0.036 \\
(0.026)\end{array}$ \\
\hline Years & Included \\
\hline Observations & 304 \\
\hline Number of groups & 43 \\
\hline VIF & 2.36 \\
\hline $\mathrm{z} 1$ & $52.04 * * *$ \\
\hline $\mathrm{z} 2$ & $18.79 * * *$ \\
\hline $\mathrm{m} 2$ & -1.46 \\
\hline Hansen & 17.84 \\
\hline
\end{tabular}


Table 4 (continued)

CSR is the amount allocated to social work (obra social) divided by net benefit; POLITICIAN is the proportion of directors representing local and regional governments or who were affiliated with a political party; LIBERAL_REGIONALIST is the proportion of political directors linked to liberal and regionalist political parties; LIBERAL_NONREGIONALIST is the proportion of political directors linked to liberal but not regionalist political parties; REGIONALIST_ NONLIBERAL is the proportion of political directors linked to regionalist but not liberal political parties; BOARD_SIZE is the size of the caja's board; EDUCATION is the Blau index considering seven branches of knowledge: arts and humanities, business and economics, engineering, health sciences, law, sciences, and social sciences; GENDER is the proportion of women on the board; SIZE is the total assets of the savings bank in thousand euros; ROE is the ratio of equity divided by its net profit; CAR is the ratio of net assets divided by its total assets (Capital Adequacy Ratio). GAP is the total loans to clients divided by total deposits to clients; CREDIT_RISK is the volume of losses on credit investments divided by total loans to clients; REGION_OFFICES is the number of regions in which the caja has offices; REGION_GDP is the GDP per capita of the region in which the caja was constituted; ELECTIONS is a dummy variable that equals 1 in the year in which there are elections in the region in which the caja was constituted

VIF, variance inflation factor to verify there are no multicollinearity problems in the models; $z 1$, Wald test of the joint significance of the reported coefficients, asymptotically distributed as $\chi^{2}$ under the null hypothesis of no relationship; $z 2$, Wald test of the joint significance of the time dummies, asymptotically distributed as $\chi^{2}$ under the null hypothesis of no relationship; $\mathrm{m} 2$, second-order serial correlation relation in the first-difference residuals, asymptotically distributed as $\mathrm{N}(0,1)$, under the null hypothesis of no serial correlation; Hansen test of over-identifying restrictions, under the null hypothesis that all instruments are uncorrelated with the disturbance process

$* p<0.10, * * p<0.05, * * * p<0.01$. In parentheses, t-statistics based on robust standard errors

${ }^{\dagger}$ The values of POLITICIAN, LIBERAL and REGIONALIST were standardized when included with the interacted variable

\section{Discussion and conclusions}

Our study focuses on the corporate decision-making of political directors by considering the heterogeneity of their behavior on the basis of two dimensions: political ideology and regional identity. Specifically, we explore the role of political directors in the CSR of Spanish cajas during the period 2004-2013. To do this, we analyze the political connections of 1578 directors, examining their personal characteristics in terms of political ideology (through their affiliation with a liberal political party) and regional identity (through their affiliation with a regionalist party).

Our results indicate that political directors favor the allocation of resources to CSR, which corresponds with limited previous evidence drawn mostly from samples of Chinese companies (Wang et al. 2018, 2021; Xu and Liu 2020; Yu and Chi 2021). Therefore, it seems that political directors promote CSR policy in cajas to improve 
the legitimacy of the entities and their own legitimacy as political directors. On the one hand, this legitimacy is especially important in businesses such as the financial industry, which is perceived by society as a rent-seeking activity (Zingales 2015). On the other hand, boosting investment in CSR allows political directors to justify or legitimize their role as directors, defending the interests of society in its entirety.

We also found that this relationship between political directors and CSR is moderated by both directors' ideology and identity. On the one hand, when considering political directors' ideology, we find a twofold positive effect on CSR, i.e., they have a direct effect on CSR and an indirect effect by reinforcing the relationship between board politicization and social projects. Our results are consistent with all previous studies on CEOs' (Chin et al. 2013; Di Giuli and Kostovetsky 2014; Gupta et al. 2019; Jeong and Kim 2020) and directors' (Di Giuli and Kostovetsky 2014) ideology, demonstrating that liberal directors are especially likely to promote CSR. Thus, we find evidence regarding the concern of liberal political directors on reducing inequality and promoting a fairer and egalitarian society by favoring an increase in CSR. On the other hand, we find that regional identity acts as a booster (indirect effect) for politicians on the board to support CSR, although it lacks the direct influence that we described above for ideology. This result corresponds with those found in the literature on hometown favoritism of political directors promoting local corporate investments (e.g., Chen et al. 2020; Guo et al. 2021) or with studies on the spending preferences in the public sector by politicians with regional identity in order to consolidate/expand a regional identity to its citizens (Jacobsen 2006). The caja's CSR activities were mainly implemented in the region where it maintained its financial activity and with which the political directors identified themselves. Therefore, our results suggest that these regionalist directors promote the expansion of spending policies (through CSR activities) in their region.

Moreover, when we analyze both personal characteristics-liberal ideology and regional identity - of political directors, we find that the most influential effect on CSR comes from liberal politicians, whether or not they have a regional identity. Thus, in terms of CSR investment, the ideology of directors seems to prevail over their regional identity.

Finally, our study explores the investment in CSR in terms of allocation to different projects (culture, health assistance, education, and heritage), and emphasizes various existing differences depending on the ideology and identity of the political directors. Thus, although both liberal and regional politicians defend cultural and health assistance projects (the two most relevant fields of CSR investment), only liberal political directors seem to increase the CSR focus on historical and natural heritage projects, whereas CSR in education and research projects is only related to political directors who display regional identity. These results support the results of Toubeau and Vampa (2021), who find that ideology influences regional public spending. Such evidence allows us to draw theoretical contributions and practical implications. 


\subsection{Theoretical contributions}

First, this study considers political directors as a heterogeneous group and explores the influence of directors' ideology and regional identity as personal characteristics that determine their decisions on CSR. Thus, our research supports arguments of the legitimacy theory on the positive influence of politicians on CSR, which, beyond the effect on CSR reporting (Fernández-Gago et al. 2018; Bianchi et al. 2019; RamónLlorens et al. 2019), has been studied only in the Chinese context. In addition, our study helps to build a theoretical basis for the relationship between liberal political ideology and CSR. Thus, we support that this liberal political ideology, traditionally associated with a greater concern for the defense of social and economic equality, is conveyed in their decisions as board members. Lastly, our study contributes to the literature on the importance of regional favoritism of directors by demonstrating that regional identity reinforces the positive effect of board politicization on CSR, as it favors the allocation of resources in investments of a social nature.

Second, this study extends the literature on political directors and CSR to the study of financial entities. Financial institutions are crucial for firm and industrial expansion (Rajan and Zingales 1998; Beck and Levine 2005). In addition, by using significant societal resources, financial entities are forced to provide information to the community more frequently than other sectors, and their CSR activities are scrutinized by the media, government, and academia (Wu and Shen 2013). In addition, financial entities have different features and externalities (e.g., complex financial products and services, corporate opacity, and high regulation) that differentiate them from non-financial institutions (Heremans 2000; Levine 2004). However, no literature exists on political directors and CSR investments in these entities. To date, only two studies exist on this topic, and they find a negative influence of political directors on CSR disclosure (Jahid et al. 2020; Rashid and Hossain 2021). Thus, this study constitutes an important cornerstone in the development of a theoretical framework for this type of entity in terms of the analysis of their CSR decisions.

Finally, previous research addressing cajas' governance has revealed the dark side of political directors testing a negative impact on cajas' performance (e.g., Azofra and Santamaría 2004; García-Meca and Sánchez-Ballesta 2014; Andres et al. 2021). Here, our research emphasizes the bright side of political directors in their positive influence on CSR, as the obra social of these cajas had a high impact on the development of the regions in which they were established (e.g., financing cultural proposals, subsidizing retirement homes, providing funding for the restoration of the region's historical heritage, etc.).

\subsection{Managerial implications}

Our study provides a guide to managers, investors, and policymakers with knowledge about how the ideology and identity of politicians on boards may influence their decision-making in relation to CSR. This kind of information related to political affiliation (and also to ideology and regional identity) is not usually included (neither recommended by codes of good governance to be included) in directors' 
profiles. However, to better understand the effect of directors on CSR, it is not only interesting to know whether they have or previously had political affiliation, but also which party they are affiliated with, as we have shown in this study.

Investors and managers should be especially aware of the different effects these directors have on CSR, depending on the kind of activity they support. Thus, while previous literature has pointed out that politicians have a predilection for investment in social action versus the environment (e.g., Xu and Liu 2020; Luo and Wang 2021), here we see that considering ideology and identity, we also find preferences such as education in the case of regionalists (perhaps because it is a clear vehicle for transmitting regional identity), or historical, artistic, and natural heritage in the case of liberals. In this sense, before hiring a politician on a board, it is important to assess whether their interests fit those of the company.

\subsection{Limitations and future research}

We have characterized the directors' ideology and identity based upon their political affiliation to a political party, but it could be interesting to extend this analysis to directors who exhibit no explicit political connections, as is conducted in the United States where public data about donations to political parties is available.

In this study, we tested the influence of political directors on CSR. However, the real motivations that drive political directors to increase CSR remain unclear, possibly because the theoretical arguments range from their greater concern for social interests - the social view approach - to their personal motivations to reduce the possibility of criticism from dissatisfied stakeholders—board entrenchment—or to improve their reputation and position in the political party. It would be interesting in future research to conduct qualitative research to elucidate this issue.

In this study, we specifically test political directors' heterogeneity in CSR policy, yet there is another important field of study that analyzes how other corporate decisions, such as debt, investment, or risk taking, may be influenced.

Finally, the study of political ideology and regional identity opens the door to new research that analyzes their influence not only in isolation but also in conjunction with other variables. Thus, one interesting aspect would be to explore how these board director variables interact with other personal characteristics. From a social point of view, it is interesting to note that political ideology or regional identity could, in many cases, become the dominant factor in decision-making over and above other factors, such as professional experience or knowledge. In more colloquial terms, in certain circumstances (in what context?) and in certain people (what kind of people, and with what personal and professional characteristics?) political ideology dominates individuals' decision-making. These questions also apply to the role of regional identity, especially in countries such as Spain, Belgium, Canada, and the UK, where regional identity is strong in certain areas (e.g., the Basque Country, Catalonia, Flanders, Quebec, 
Scotland, Wales, etc.). Undoubtedly, the study of the influence of directors' ideology and identity on corporate decision-making presents numerous fascinating issues.

\section{Appendix}

See Tables 5 and 6.

Table 5 Identification of each political party according to its liberal ideology and regional identity. Source: Own elaboration and Massetti and Schakel (2015)

\begin{tabular}{lll}
\hline Political party & Liberal & Regionalist \\
\hline Partido Socialista Obrero Español & 1 & 0 \\
Partido Popular & 0 & 0 \\
Izquierda Unida & 1 & 0 \\
Partido Nacionalista Vasco & 0 & 1 \\
Convergencia i Unió & 0 & 1 \\
Partido Galeguista & 0 & 1 \\
Bloque Nacionalista Gallego & 1 & 1 \\
Partido andalucista & 1 & 1 \\
Convergencia por Extremadura & 1 & 1 \\
Unión del Pueblo Navarro & 0 & 1 \\
Independents pel Progrés Municipal d'Osona & 1 & 1 \\
Mes per Santa Eugenia & 1 & 1 \\
Unión del Pueblo Leonés & 0 & 1 \\
Coalición Canaria & 0 & 1 \\
Nueva Canarias & 1 & 1 \\
La Fortaleza de Santa Lucia & 0 & 1 \\
Unio Mollera Pollencina & 0 & 1 \\
Unió mallorquina & 0 & 1 \\
Esquerra Republicana de Catalunya & 1 & 1 \\
Iniciativa Per Catalunya & 1 & 1 \\
Coalició Progress Municipal & 1 & 1 \\
Unión de Centro Democrático & 0 & 0 \\
Chunta Aragonesista & 1 & 1 \\
Euskal Herria Bildu & 1 & 1 \\
Partido Aragonés Demócrata Liberal & 0 & 1 \\
Aralar & 1 & 1 \\
Eusko Alkartasuna & 1 & 1 \\
Partido Aragonés & 0 & 1 \\
Partido Regionalista de Cantabria & 0 & 1 \\
\hline & & \\
\hline
\end{tabular}


Table 6 Definition of variables

\begin{tabular}{|c|c|}
\hline Variables & Definition \\
\hline CSR & Amount allocated to social work (obra social) divided by net benefit \\
\hline CSR_CULTURE & Amount allocated to cultural activities divided by net benefit \\
\hline CSR_HEALTH & $\begin{array}{l}\text { Amount allocated to health and social assistance divided by net } \\
\text { benefit }\end{array}$ \\
\hline CSR_EDUCATION & Amount allocated to education and research divided by net benefit \\
\hline CSR_HERITAGE & $\begin{array}{l}\text { Amount allocated to historical, artistic and natural heritage divided } \\
\text { by net benefit }\end{array}$ \\
\hline POLITICIAN & $\begin{array}{l}\text { Proportion of directors representing local and regional governments } \\
\text { or who were affiliated with a political party }\end{array}$ \\
\hline LIBERAL & Proportion of political directors linked to liberal political parties \\
\hline REGIONALIST & Proportion of political directors linked to regionalist political parties \\
\hline LIBERAL_REGIONALIST & $\begin{array}{l}\text { Proportion of political directors linked to liberal and regionalist } \\
\text { political parties }\end{array}$ \\
\hline LIBERAL_NONREGIONALIST & $\begin{array}{l}\text { Proportion of political directors linked to liberal but not regionalist } \\
\text { political parties }\end{array}$ \\
\hline REGIONALIST_NONLIBERAL & $\begin{array}{l}\text { Proportion of political directors linked to regionalist but not liberal } \\
\text { political parties }\end{array}$ \\
\hline BOARD_SIZE & $\begin{array}{l}\text { Size of the caja's board of directors (in logarithm in explanatory } \\
\text { analyses) }\end{array}$ \\
\hline EDUCATION & $\begin{array}{l}\text { Blau index }\left(1-\sum\left(\mathrm{P}_{\mathrm{i}}\right)^{2}\right) \text { considering seven branches of knowledge: } \\
\text { arts and humanities, business and economics, engineering, health } \\
\text { sciences, law, sciences, and social sciences }\end{array}$ \\
\hline GENDER & Proportion of women on the board of directors \\
\hline SIZE & $\begin{array}{l}\text { Total assets of the savings bank in million euros (in logarithm in } \\
\text { explanatory analyses) }\end{array}$ \\
\hline ROE & Return on Equity. Ratio of equity divided by its net profit \\
\hline CAR & Capital Adequacy Ratio. Ratio of net assets divided by its total assets \\
\hline GAP & Total loans to clients divided by total deposits to clients \\
\hline CREDIT_RISK & Losses on credit investments divided by total loans to clients \\
\hline REGION_OFFICES & $\begin{array}{l}\text { Number of regions in which the caja has offices (in logarithm in } \\
\text { explanatory analyses) }\end{array}$ \\
\hline REGION_GDP & $\begin{array}{l}\text { GDP per capita of the region in which the caja was constituted (in } \\
\text { logarithm in explanatory analyses) }\end{array}$ \\
\hline ELECTIONS & $\begin{array}{l}\text { Dummy variable that takes a value of " } 1 \text { " in the year in which there } \\
\text { are elections in the region in which the caja was constituted, and } \\
\text { " } 0 \text { " otherwise }\end{array}$ \\
\hline
\end{tabular}

Funding Open Access funding provided thanks to the CRUE-CSIC agreement with Springer Nature. This study was supported by the Spanish Ministry of Economy and Competitiveness (Grant ECO201785356), the UAM - Comunidad de Madrid (SI3-PJI-2021-00276) and it benefited from the Professorship Excellence Program in accordance with the multi-year agreement signed by the Government of Madrid and the Autonomous University of Madrid (Line \#3). 


\section{Declarations}

Conflict of interest The authors declare that there is no conflict of interest.

Open Access This article is licensed under a Creative Commons Attribution 4.0 International License, which permits use, sharing, adaptation, distribution and reproduction in any medium or format, as long as you give appropriate credit to the original author(s) and the source, provide a link to the Creative Commons licence, and indicate if changes were made. The images or other third party material in this article are included in the article's Creative Commons licence, unless indicated otherwise in a credit line to the material. If material is not included in the article's Creative Commons licence and your intended use is not permitted by statutory regulation or exceeds the permitted use, you will need to obtain permission directly from the copyright holder. To view a copy of this licence, visit http://creativecommons.org/licen ses/by/4.0/.

\section{References}

Abrams D, Hogg MA (1990) Social identification, self-categorization and social influence. Eur Rev Soc Psychol 1(1):195-228. https://doi.org/10.1080/14792779108401862

Andres P, Garcia-Rodriguez I, Romero-Merino ME, Santamaria-Mariscal M (2021) Politicians in disguise and financial experts on the board: evidence from Spanish cajas. BRQ Bus Res Q 24(2):174-191. https://doi.org/10.1177/2340944420924417

Arellano M, Bover O (1990) La econometría de datos de panel [The econometrics of panel data]. Investigaciones Económicas 14:3-45

Atkinson AB, Stiglitz JE (1980) Lectures on public economics. MCGraw-Hill, London

Azofra V, Santamaría M (2004) El gobierno de las cajas de ahorro españolas [The governance of Spanish savings banks]. Universia Bus Rev 2(2):48-59

Beck T, Levine R (2005) Legal institutions and financial development. In: Menard C, Shirley MM (eds) Handbook of new institutional economics. Springer, Boston, pp 251-278. https://doi.org/ 10.1007/0-387-25092-1_12

Beland D, Lecours A (2008) Nationalism and social policy. The politics of territorial solidarity. Oxford University Press, Oxford

Bianchi MT, Monteiro P, Azevedo G, Oliveira J, Viana RC, Branco MC (2019) Political connections and corporate social responsibility reporting in Portugal. J Financ Crime 26(4):1203-1215. https://doi.org/10.1108/JFC-10-2018-0111

Blundell R, Bond S (2000) GMM estimation with persistent panel data: an application to production functions. Econ Rev 19:321-340. https://doi.org/10.1080/07474930008800475

Bond S (2002) Dynamic panel data models: a guide to micro data methods and practice. Portug Econ J 1:141-162. https://doi.org/10.1007/s10258-002-0009-9

Briscoe F, Chin MK, Hambrick DC (2014) CEO ideology as an element of the corporate opportunity structure for social activists. Acad Manag J 57(6):1786-1809. https://doi.org/10.5465/amj.2013. 0255

Burgess R, Jedwab R, Miguel E, Morjaria A, Padró i Miquel G, (2015) The value of democracy: evidence from road building in Kenya. Am Econ Rev 105(6):1817-1851. https://doi.org/10.1257/aer.20131 031

Cabeza-García L, Martínez-Campillo A, Marbella-Sánchez F (2010) Corporate social responsibility and business performance: the case of social work at Spanish savings banks. Innovar Revista de Ciencias Administrativas y Sociales 20(37):33-46

Cabeza-García L, Fernández-Gago R, Nieto M (2018) Do board gender diversity and director typology impact CSR reporting? Eur Manag Rev 15(4):559-575. https://doi.org/10.1111/emre.1214

Cardone-Riportella C, Samaniego-Medina R, Trujillo-Ponce A (2010) What drives bank securitisation? The Spanish experience. J Bank Financ 34(11):2639-2651. https://doi.org/10.1016/j.jbankfin.2010. 05.003

Carney DR, Jost JT, Gosling SD, Potter J (2008) The secret lives of liberals and conservatives: personality profiles, interaction styles, and the things they leave behind. Polit Psychol 29(6):807-840. https://doi.org/10.1111/j.1467-9221.2008.00668.x 
Castelló I, Etter M, Årup Nielsen F (2016) Strategies of legitimacy through social media: the networked strategy. J Manag Stud 53(3):402-432. https://doi.org/10.1111/joms.12145

Chen JJ, Cheng X, Gong SX, Tan Y (2017) Implications of political patronage and political costs for corporate disclosure: evidence from the Shanghai Pension corruption scandal. J Account Audit Financ 32(1):2-122. https://doi.org/10.1177/0148558X15579491

Chen Y, Cui C, Yang T, Zhang X (2020) Political favouritism and investment efficiency. Pac-Basin Financ J 61:101058. https://doi.org/10.1016/j.pacfin.2018.08.012

Chin MK, Hambrick DC, Treviño LK (2013) Political ideologies of CEOs: the influence of executives' values on corporate social responsibility. Adm Sci Q 58(2):197-232. https://doi.org/10.1177/00018 39213486984

Chiu SC, Sharfman M (2011) Legitimacy, visibility, and the antecedents of corporate social performance: an investigation of the instrumental perspective. J Manag 37(6):1558-1585. https://doi.org/10. $1177 / 0149206309347958$

Claessens SF, E, Laeven, L, (2008) Political connections and preferential access to finance: the role of campaign contributions. J Financ Econ 88(3):554-580. https://doi.org/10.1016/j.jfineco.2006.11. 003

Crane A, Ruebottom T (2011) Stakeholder theory and social identity: rethinking stakeholder identification. J Bus Ethics 102(1):77-87. https://doi.org/10.1007/s10551-011-1191-4

Daily C, Schwenk C (1996) Chief executive officers, top management teams and boards oi directors: congruent or countervailing forces? J Manag 22:185-202. https://doi.org/10.1177/014920639602200 201

De Winter L, Türsan H (eds) (1998) Regionalist parties in Western Europe. Routledge, London

Deegan CM (2019) Legitimacy theory: despite its enduring popularity and contribution, time is right for a necessary makeover. Account Audit Account J 32(8):2307-2329. https://doi.org/10.1108/ AAAJ-08-2018-3638

Devine CJ (2015) Ideological social identity: psychological attachment to ideological in-groups as a political phenomenon and a behavioral influence. Polit Behav 37(3):509-535. https://doi.org/10. 1007/s11109-014-9280-6

Di Giuli A, Kostovetsky L (2014) Are red or blue companies more likely to go green? Politics and corporate social responsibility. J Financ Econ 111(1):158-180. https://doi.org/10.1016/j.jfineco.2013. 10.002

Dinç S (2005) Politicians and banks: political influences on government-owned banks in emerging countries. J Financ Econ 77:453-459. https://doi.org/10.1016/j.jfineco.2004.06.011

Dowling J, Pfeffer J (1975) Organizational legitimacy: social values and organizational behavior. Pac Soc Rev 18(1):122-136. https://doi.org/10.2307/1388226

Erikson RS, Tedin KL (2003) American public opinion. Longman, New York

Evans G, Health A, Lalljee M (1996) Measuring left-right and libertarian-authoritarian values in the British electorate. Br J Sociol 47(1):93-112. https://doi.org/10.2307/591118

Fernández-Ferrín P, Castro-González S, Bande B (2021) Corporate social responsibility, emotions, and consumer loyalty in the food retail context: exploring the moderating effect of regional identity. Corp Soc Responsib Environ Manag 28(2):648-666

Fernández-Gago R, Cabeza-García L, Nieto M (2018) Independent directors' background and CSR disclosure. Corp Soc Responsib Environ Manag 25(5):991-1001. https://doi.org/10.1002/csr.1515

Finkel SE, Scarrow HA (1985) Party identification and party enrollment: the difference and the consequences. J Polit 47(2):620-642. https://doi.org/10.1002/csr.2077

Fiva JH, Halse AH (2016) Local favoritism in at-large proportional representation systems. J Public Econ 143:15-26. https://doi.org/10.1016/j.jpubeco.2016.08.002

Garanina T, Aray Y (2021) Enhancing CSR disclosure through foreign ownership, foreign board members, and cross-listing: does it work in Russian context? Emerg Mark Rev 46:100754. https://doi. org/10.1016/j.ememar.2020.100754

García-Cestona M, Surroca J (2008) Multiple goals and ownership structure: effects on the performance of Spanish savings banks. Eur J Oper Res 187(2):582-599. https://doi.org/10.1016/j.ejor.2007.03. 028

García-Meca E (2016) Political connections, gender diversity and compensation policy. Rev Manag Sci 10(3):553-576. https://doi.org/10.1007/s11846-015-0167-7

García-Meca E, Palacio CJ (2018) Board composition and firm reputation: the role of business experts, support specialists and community influentials. BRQ Bus Res Q 21(2):111-123. https://doi.org/10. 1016/j.brq.2018.01.003 
García-Meca E, Sánchez-Ballesta JP (2014) Politicization, banking experience and risk in savings banks. Eur J Law Econ 38(3):535-553. https://doi.org/10.1007/s10657-012-9377-5

Goldman E, Rocholl J, So J (2009) Do politically connected boards affect firm value? Rev Financ Stud 22:2331-2360. https://doi.org/10.1093/rfs/hhn088

Gomez-Carrasco P, Guillamon-Saorin E, Osma BG (2016) The illusion of CSR: drawing the line between core and supplementary CSR. Sustain Account Manag Policy J 7(1):125-151. https://doi.org/10. 1108/SAMPJ-12-2014-0083

Goren P, Federico CM, Kittilson MC (2009) Source cues, partisan identities, and political value expression. Am J Polit Sci 53(4):805-820. https://doi.org/10.1111/j.1540-5907.2009.00402.x

Greene S (1999) Understanding party identification: a social identity approach. Polit Psychol 20:393403. https://doi.org/10.1111/0162-895X.00150

Guerra Pérez S, Bona Sánchez C, Santana Martín DJ (2015) Politically connected firms in Spain. BRQ Bus Res Q 18:230-245. https://doi.org/10.1016/j.brq.2014.10.002

Guo P, Shi G, Tian GG, Duan S (2021) Politicians' hometown favoritism and corporate investments: the role of social identity. J Bank Financ 125:106092. https://doi.org/10.1016/j.jbankfin.2021.106092

Gupta A, Wowak AJ (2017) The elephant (or donkey) in the boardroom: how board political ideology affects CEO pay. Adm Sci Q 62(1):1-30. https://doi.org/10.1177/0001839216668173

Gupta A, Nadkarni S, Mariam M (2019) Dispositional sources of managerial discretion: CEO ideology, CEO personality, and firm strategies. Adm Sci Q 64(4):855-893. https://doi.org/10.1177/00018 39218793128

Hambrick D, D'Aveni R (1992) Top team deterioration as part of the downward spiral of large corporate bankruptcies. Manag Sci 38:1445-1466. https://doi.org/10.1287/mnsc.38.10.1445

Häuszer K, Frey HP (1987) Identität. Enke, Stuttgart

Heremans D (2000) Regulation of banking and financial markets. In: Bouckaert B, De Geest G (eds) Encyclopedia of law and economics. Edward Elgar Publishing, Cheltenham, pp 950-986. https:// doi.org/10.4337/9781782540465.00023

Hillman AJ, Dalziel T (2003) Boards of directors and firm performance: integrating agency and resource dependence perspectives. Acad Manag Rev 28(3):383-396. https://doi.org/10.5465/amr.2003. 10196729

Hodler R, Raschky PA (2014) Regional favoritism. Q J Econ 129(2):995-1033. https://doi.org/10.1093/ qje/qju004

Hughes N (2011) 'Young people took to the streets and all of a sudden all of the political parties got old': the 15M movement in Spain. Soc Mov Stud 10(4):407-413. https://doi.org/10.1080/14742 837.2011.614109

Ispas A (2012) Psychology and the social identity perspective. In: Ispas A (ed) Psychology and politics. Psychology Press, Hove, pp 13-37

Jacobsen DI (2006) Public sector growth: comparing politicians' and administrators' spending preferences. Public Adm 84(1):185-204. https://doi.org/10.1111/j.0033-3298.2006.00499.x

Jahid MA, Rashid MHU, Hossain SZ, Haryono S, Jatmiko B (2020) Impact of corporate governance mechanisms on corporate social responsibility disclosure of publicly-listed banks in Bangladesh. J Asian Financ Econ Bus 7(6):61-71. https://doi.org/10.13106/jafeb.2020.vol7.no6.061

Jensen C (2010) Issue compensation and right-wing government social spending. Eur J Polit Res 49(2):282299. https://doi.org/10.1111/j.1475-6765.2009.01898.x

Jeong N, Kim N (2020) The effects of political orientation on corporate social (ir) responsibility. Manag Decis 58(2):255-266. https://doi.org/10.1108/MD-06-2019-0713

Johnson AF, Roberto KJ (2019) Elections and selection: the role of political ideology in selection decisions. Hum Resour Manag Rev 29(1):14-27. https://doi.org/10.1016/j.hrmr.2018.05.003

Johnson JL, Daily CM, Ellstrand AE (1996) Boards of directors: a review and research agenda. J Manag 22(3):409-438. https://doi.org/10.1177/014920639602200303

Jost JT (2006) The end of the end of ideology. Am Psychol 61(7):651-670. https://doi.org/10.1037/0003066X.61.7.651

Jost JT, Glaser J, Kruglanski AW, Sulloway F (2003) Exceptions that prove the rule: using a theory of motivated social cognition to account for ideological incongruities and political anomalies. Psychol Bull 129(3):383-393. https://doi.org/10.1037/0033-2909.129.3.383

Jost JT, Federico CM, Napier JL (2009) Political ideology: its structure, functions, and elective affinities. Annu Rev Psychol 60:307-337. https://doi.org/10.1146/annurev.psych.60.110707.163600

Jouber H (2021) Is the effect of board diversity on CSR diverse? New insights from one-tier vs two-tier corporate board models. Corp Gov Int J Bus Soc 21(1):23-61. https://doi.org/10.1108/CG-07-2020-0277 
Kaczmarek S, Kimino S, Pye A (2012) Antecedents of board composition: the role of nomination committees. Corp Gov Int Rev 20(5):474-489. https://doi.org/10.1111/j.1467-8683.2012.00913.x

Lantz G, Loeb S (1998) An examination of the community identity and purchase preferences using the social identity approach. ACR North Am Adv 25:486-491

Levine R (2004) The corporate governance of banks: a concise discussion of concepts and evidence. World Bank Policy Research Paper, vol 3404. https://doi.org/10.1596/1813-9450-3404

Li S, Song X, Wu H (2015) Political connection, ownership structure, and corporate philanthropy in China: a strategic-political perspective. J Bus Ethics 129(2):399-411. https://doi.org/10.1007/ s10551-014-2167-y

Lin KJ, Tan J, Zhao L, Karim K (2015) In the name of charity: political connections and strategic corporate social responsibility in a transition economy. J Corp Financ 32:327-346. https://doi.org/10.1016/j. jcorpfin.2014.10.007

López Iturriaga FJ, Cepeda R, Durán CD, PV, Ansola ES, (2007) La obra social de las cajas de ahorros: un análisis exploratorio [The social work of savings banks: an exploratory analysis]. Universia Bus Rev 14:84-95

Luo XR, Wang D (2021) Are politically endorsed firms more socially responsible? Selective engagement in corporate social responsibility. J Bus Ethics 170(3):535-555. https://doi.org/10.1007/ s10551-019-04367-6

Markoczy L, Sun SL, Zhu J (2020) Few women on boards: what's identity got to do with it? J Bus Ethics 165(2):311-327. https://doi.org/10.1007/s10551-019-04104-Z

Marquis C, Qian C (2014) Corporate social responsibility reporting in China: symbol or substance? Organ Sci 25(1):127-148. https://doi.org/10.1287/orsc.2013.0837

Massetti E, Schakel AH (2015) From class to region: how regionalist parties link (and subsume) left-right into centre-periphery politics. Party Polit 21(2):866-886. https://doi.org/10.1177/1354068815597577

Mooney G, Scott G (2011) Social justice, social welfare and devolution: nationalism and social policy making in Scotland. Poverty Public Policy 3(4):1-21. https://doi.org/10.2202/1944-2858.1109

Paasi A (2003) Region and place: regional identity in question. Prog Hum Geogr 27(4):475-485. https://doi. org/10.1191/0309132503ph439pr

Piattoni S (2001) Clientelism in historical and comparative perspective. In: Piattoni S (ed) Clientelism, interests, and democratic representation: the European experience in historical and comparative perspective. Cambridge University Press, Cambridge, pp 1-30

Pontusson J, Rueda D (2010) The politics of inequality: voter mobilization and left parties in advanced industrial states. Comp Pol Stud 43(6):675-705. https://doi.org/10.1177/0010414009358672

Potrafke N (2011) Does government ideology influence budget composition? Empirical evidence from OECD countries. Econ Gov 12(2):101-134. https://doi.org/10.1007/s10101-010-0092-9

Raagmaa G (2002) Regional identity in regional development and planning. Eur Plan Stud 10(1):55-76. https://doi.org/10.1080/09654310120099263

Rajan R, Zingales L (1998) Financial dependence and growth. Am Econ Rev 88(3):559-586

Ramón-Llorens MC, García-Meca E, Pucheta-Martínez MC (2019) The role of human and social board capital in driving CSR reporting. Long Range Plann 52(6):101846. https://doi.org/10.1016/j.lrp.2018.08. 001

Rashid MHU, Hossain SZ (2021) Does board independence moderate the effect of politician directors on CSR disclosure? Evidence from the publicly listed banks in Bangladesh. Soc Responsib J. https://doi. org/10.1108/SRJ-08-2020-0320

Raskovic M, Takacs-Haynes K (2021) (Re)discovering social identity theory: an agenda for multinational enterprise internalization theory. Multinat Bus Rev 29(2):145-165. https://doi.org/10.1108/ MBR-02-2020-0031

Rowley TI, Moldoveanu M (2003) When will stakeholder groups act? An interest-and identity-based model of stakeholder group mobilization. Acad Manag Rev 28(2):204-219. https://doi.org/10.5465/amr. 2003.9416080

Shi W, Tang Y (2015) Cultural similarity as in-group favoritism: the impact of religious and ethnic similarities on alliance formation and announcement returns. J Corp Financ 34:32-46. https://doi.org/10. 1016/j.jcorpfin.2015.07.003

Shi W, Connelly BL, Mackey JD, Gupta A (2019) Placing their bets: the influence of strategic investment on CEO pay-for-performance. Strateg Manag J 40(12):2047-2077. https://doi.org/10.1002/smj.3050

Suchman MC (1995) Managing legitimacy: strategic and institutional approaches. Acad Manag Rev 20(3):571-610. https://doi.org/10.5465/amr.1995.9508080331 
Tajfel H, Turner JC (1986) The social identity theory of intergroup behavior. In: Worchel S, Austin WG (eds) Psychology of intergroup relations. Nelson-Hall, Chicago, pp 7-24

Tedin KL (1987) Political ideology and the vote. Res Micropolit 2(1):63-94

Tetlock PE, Vieider FM, Patil SV, Grant AM (2013) Accountability and ideology: when left looks right and right looks left. Organ Behav Hum Decis Process 122(1):22-35. https://doi.org/10.1016/j.obhdp.2013. 03.007

Toubeau S, Vampa D (2021) Adjusting to austerity: the public spending responses of regional governments to the budget constraint in Spain and Italy. J Public Policy 41(3):462-488. https://doi.org/10.1017/ S0143814X20000094

Villarón-Peramato Ó, Martínez-Ferrero J, García-Sánchez IM (2018) CSR as entrenchment strategy and capital structure: corporate governance and investor protection as complementary and substitutive factors. Rev Manag Sci 12(1):27-64. https://doi.org/10.1007/s11846-016-0212-1

Wang Z, Reimsbach D, Braam G (2018) Political embeddedness and the diffusion of corporate social responsibility practices in China: a trade-off between financial and CSR performance? J Clean Prod 198:1185-1197. https://doi.org/10.1016/j.jclepro.2018.07.116

Wang Y, Ma J, Wang T (2021) Do all female directors have the same impact on corporate social responsibility? The role of their political connection. Asia Pac J Manag. https://doi.org/10.1007/ s10490-021-09754-0

Wöcke A, Grosse R, Stacey A, Brits N (2018) Social identity in MNCs based on language and nationality. Thunderbird Inter Bus Rev 60(4):661-673. https://doi.org/10.1002/tie.21953

Wu MW, Shen CH (2013) Corporate social responsibility in the banking industry: motives and financial performance. J Bank Financ 37(9):3529-3547. https://doi.org/10.1016/j.jbankfin.2013.04.023

Xiang Y, Jia M, Zhang Z (2021) Hiding in the crowd: government dependence on firms, management costs of political legitimacy, and modest imitation. J Bus Ethics. https://doi.org/10.1007/s10551-020-04709-9

Xu S, Liu D (2020) Political connections and corporate social responsibility: political incentives in China. Bus Ethics Eur Rev 29(4):664-693. https://doi.org/10.1111/beer.12308

Yu Y, Chi J (2021) Political embeddedness, media positioning and corporate social responsibility: evidence from China. Emerg Mark Rev 47:100799. https://doi.org/10.1016/j.ememar.2021.100799

Zahra SA, Pearce JA (1989) Boards of directors and corporate financial performance: a review and integrative model. J Manag 15(2):291-334. https://doi.org/10.1177/014920638901500208

Zhang C (2017) Political connections and corporate environmental responsibility: adopting or escaping? Energy Econ 68:539-547. https://doi.org/10.1016/j.eneco.2017.10.036

Zhang J, Marquis C, Qiao K (2016) Do political connections buffer firms from or bind firms to the government? A study of corporate charitable donations of Chinese firms. Organ Sci 27(5):1307-1324. https://doi.org/10.1287/orsc.2016.1084

Zingales L (2015) Presidential address: does finance benefit society? J Financ 70(4):1327-1363. https://doi. org/10.1111/jofi.12295

Publisher's Note Springer Nature remains neutral with regard to jurisdictional claims in published maps and institutional affiliations. 